\title{
On the visibility of airborne volcanic ash and mineral dust from the pilot's perspective in flight
}

\author{
Bernadett Weinzierl ${ }^{\mathrm{a}, \mathrm{b}, *}$, Daniel Sauer ${ }^{\mathrm{b}, \mathrm{a}}$, Andreas Minikin ${ }^{\mathrm{a}}$, Oliver Reitebuch ${ }^{\mathrm{a}}$, Florian Dahlkötter ${ }^{\mathrm{a}}$, \\ Bernhard Mayer $^{\mathrm{b}}$, Claudia Emde ${ }^{\mathrm{b}}$, Ina Tegen ${ }^{\mathrm{c}}$, Josef Gasteiger ${ }^{\mathrm{b}}$, Andreas Petzold ${ }^{\mathrm{a}}$, Andreas Veira ${ }^{\mathrm{a}}$, \\ Ulrich Kueppers ${ }^{\mathrm{d}}$, Ulrich Schumann ${ }^{\mathrm{a}}$
}

a Deutsches Zentrum für Luft- und Raumfahrt (DLR), Institut für Physik der Atmosphäre, 82234 Oberpfaffenhofen, Germany
b Ludwig-Maximilians-Universität München, Meteorologisches Institut, Theresienstraße 37, 80333 München, Germany
${ }^{\mathrm{c}}$ Leibniz Institute for Tropospheric Research (IfT), Physics Department, Permoserstraße 15, 04318 Leipzig, Germany
${ }^{\mathrm{d}}$ Ludwig-Maximilians-Universität München, Geo- und Umweltwissenschaften, Theresienstraße 41, 80333 München, Germany

\section{A R T I C L E I N F O}

\section{Article history:}

Available online 27 April 2012

This paper is dedicated to the memory of our friend and outstanding technician Hans Rüba $(† 2011)$, who was involved in all those aircraft missions.

\section{Keywords:}

Volcanic ash

Saharan mineral dust

Particle size distribution

Visible ash

Ash mass concentration

Radiative transfer simulations

\begin{abstract}
A B S T R A C T
In April 2010, volcanic ash from the Eyjafjalla volcano in Iceland strongly impacted aviation in Europe. In order to prevent a similar scenario in the future, a threshold value for safe aviation based on actual mass concentrations was introduced ( $2 \mathrm{mg} \mathrm{m}^{-3}$ in Germany). This study contrasts microphysical and optical properties of volcanic ash and mineral dust and assesses the detectability of potentially dangerous ash layers (mass concentration larger than $2 \mathrm{mg} \mathrm{m}^{-3}$ ) from a pilot's perspective during a flight. Also the possibility to distinguish between volcanic ash and other aerosols is investigated. The visual detectability of airborne volcanic ash is addressed based on idealized radiative transfer simulations and on airborne observations with the DLR Falcon gathered during the Eyjafjalla volcanic ash research flights in 2010 and during the Saharan Mineral Dust Experiments in 2006 and 2008. Mineral dust and volcanic ash aerosol both show an enhanced coarse mode $(>1 \mu \mathrm{m})$ aerosol concentration, but volcanic ash aerosol additionally contains a significant number of Aitken mode particles $(<150 \mathrm{~nm})$ not present in mineral dust. Under daylight clear-sky conditions and depending on the viewing geometry, volcanic ash is visible already at mass concentrations far below what is currently considered dangerous for aircraft engines. However, it is not possible to visually distinguish volcanic ash from other aerosol layers or to determine whether a volcanic ash layer is potentially dangerous (mass concentration larger or smaller than $2 \mathrm{mg} \mathrm{m}^{-3}$ ). Different appearances due to microphysical differences of both aerosol types are not detectable by the human eye. Nonetheless, as ash concentrations can vary significantly over distances travelled by an airplane within seconds, this visual threat evaluation may contribute greatly to the short-term response of pilots in ash-contaminated air space.
\end{abstract}

(c) 2012 Elsevier Ltd. All rights reserved.

\section{Introduction}

Every explosive volcanic eruption is producing ash. The amount of ash generated varies between subordinate to predominant as a function of internal (magma) or external parameters. As a consequence, a single eruption may affect its direct neighbourhood only or the entire planet. Volcanic eruptions may not only impact the global climate like Pinatubo which led to a tropospheric cooling of $0.5-0.8 \mathrm{~K}$ (Parker et al., 1996), they may also pose a hazard to aviation due to adverse effects on the aircraft's engines or navigation equipment. Besides volcanic ash, also mineral dust is known to have potentially severe impact on aircraft. However, strong min-

\footnotetext{
* Corresponding author at: Deutsches Zentrum für Luft- und Raumfahrt (DLR), Institut für Physik der Atmosphäre, 82234 Oberpfaffenhofen, Germany.

E-mail address: bernadett.weinzierl@dlr.de (B. Weinzierl).
}

eral dust storms mainly affect take-off and landing of aircraft by causing very poor visibility. In contrast, volcanic ash particles are considered more dangerous to aircraft engines because they commonly have a glassy groundmass that will change its material properties upon heating. This transition from solid- to liquid-like behavior will start far below the typical melting temperatures of crystals or rocks, at temperatures met in aircraft turbines (Casadevall, 1993; Dingwell, 1996; Kueppers et al., 2010; Lavallée et al., 2012). Mechnich et al. (2011) describe the results of laboratory experiments with artificial volcanic ash and dust particles. They investigated the effects of particle deposition and high-temperature interactions on the thermal barrier coatings of high-pressure turbine airfoils. They concluded that some constituents of volcanic ash can become sufficiently liquid to cause damage on the thermal barrier coatings of turbine blades at temperatures which are generally exceeded in jet engine turbines. Aside from 
the adverse effects on turbine airfoils other damage, such as the erosion and blinding of windows or clogging of aeronautic sensors, can occur.

In the past 60 years, at least 129 planes inadvertently flew through the ash plumes originating from explosive volcanic eruptions from, for example Galunggung (1982, Java, Indonesia), Redoubt (1989/1990, Alaska, USA) or Pinatubo (1991, Philippines) volcanoes. For 79 of those encounters various degrees of airframe and engine damage were reported (Casadevall, 1993; Guffanti et al., 2010). In nine cases one or more engines temporarily failed due to the melting and resolidification of ash in the jet engine turbine, but it was possible to restart the engines in-flight (Guffanti et al., 2010). Although most of the incidents involving ash-related aircraft damage occurred at distances smaller than $1000 \mathrm{~km}$ downwind of the volcano and within the first day after the onset of the volcanic eruption, there have been exceptions with incidents at even larger distances (Casadevall, 1994; Guffanti et al., 2010). The severity of effects observed among the different volcanic ash incidents is highly variable, and the International Civil Aviation Organization (ICAO, 2001, 2007) classifies ash encounters on the basis of a severity index ranging from 0 to 5 : in the case of a class 0 encounter, only acrid smell, or electrostatic discharge (St. Elmo's fire) is noted, whereas, for example, a class 4 encounter causes temporary engine failure, but it is possible to restart the engines in-flight. So far no class 5 encounters (engine failure or other damage leading to crash) have been reported. Besides short-term effects such as engine failure, also long-term damages are observed which are primarily related to the exposure to the acidic gas sulfur dioxide (Casadevall, 1993). Although aircraft have been capable of flying safely in regions with low ash concentrations, critical concentration threshold values could not easily be defined, and the analysis of previous accidents after ash encounters did not lead to conclusive limits. Therefore, the lesson learned from these ash encounters in the 1980s and 1990s was that the only way to ensure maximum flight safety, is the complete avoidance of ash-laden air (Casadevall, 1993). The procedure recommended by ICAO (2001, 2007) was “(...) regardless of ash concentration - AVOID AVOID AVOID". In particular, it was recommended to avoid any "visible ash".

This "zero tolerance" rule lead to the closure of large parts of the European airspace for several days after the eruption of Iceland's Eyjafjalla volcano ${ }^{1}\left(63.63^{\circ} \mathrm{N}, 19.62^{\circ} \mathrm{W}, 1666 \mathrm{~m}\right.$ above sea level (a.s.l.)) in April 2010 causing the most extensive restrictions to the airspace over Europe since the end of World War II. The explosive summit eruption on 14 April 2010 followed after a phase of effusive flank eruptions (Sigmundsson et al., 2010), and the prevailing meteorological conditions subsequently led to the fast transport of volcanic ash to central Europe. The total eruption period of the Eyjafjalla (including days with almost no activity) lasted 39 days, which by far exceeded the duration of any explosive eruption phase in Iceland in the past 30 years (Petersen et al., 2012). The optically strongest ash layer (aerosol optical depth (AOD) 0.7-1.2 at $500 \mathrm{~nm}$ ) ever measured over Europe reached Germany on 16 April 2010, and peak ash mass concentrations retrieved from the lidar measurements in Leipzig and Munich showed values of 1.0 and $1.1 \mathrm{mg} \mathrm{m}^{-3}$, respectively, with an uncertainty range of $0.65-1.8 \mathrm{mg} \mathrm{m}^{-3}$ (Ansmann et al., 2010; Gasteiger et al., 2011). Airborne in situ measurements on 19 April 2010 still revealed values between 0.03 and $0.11 \mathrm{mg} \mathrm{m}^{-3}$ over Leipzig and $\mathrm{Mu}-$ nich (Schumann et al., 2011). Between 14 and 24 April 2010, up to $14 \%$ of the European atmosphere (between $10^{\circ} \mathrm{W}-30^{\circ} \mathrm{E}$ and $36^{\circ} \mathrm{N}-$ $60^{\circ} \mathrm{N}$ ) showed volcanic ash concentrations of more than $0.2 \mathrm{mg} \mathrm{m}^{-3}$ and in $1.5 \%$ of the area $2 \mathrm{mg} \mathrm{m}^{-3}$ was exceeded (Stohl et al., 2011).

\footnotetext{
1 The Eyjafjalla volcano is also referred to as Eyjafjallajökull volcano, Eyjafjallajökull, Eyjafjöll, or Eyjafjalla Glacier volcano, http://www.britannica.com/EBchecked/ topic/1683937/Eyjafjallajokull-volcano.
}

For mineral dust, concentrations of $0.2 \mathrm{mg} \mathrm{m}^{-3}$ and higher are not uncommon in regions adjacent to deserts like the Saharan desert (Schütz, 1980; Weinzierl et al., 2009), but as aforementioned volcanic ash is more dangerous to aircraft engines.

To maximize the non-restricted airspace in which aircraft could operate under a limited presence of volcanic ash, aviation experts agreed on preliminary threshold values for volcanic ash based on empirical assumptions at the end of April 2010 (Schumann et al., 2011). As a result, less frequent closures of airspaces were necessary in the later eruption phase of the Eyjafjalla volcano. On 23 May 2011, after the eruption of Iceland's Grimsvötn volcano, the German Government (http://www.bmvbs.de) regulated that aircraft may fly in volcanic ash without special attention below a concentration limit of $0.2 \mathrm{mg} \mathrm{m}^{-3}$. Between 0.2 and $2 \mathrm{mg} \mathrm{m}^{-3}$ enhanced procedures apply. Areas with concentrations above $2 \mathrm{mg} \mathrm{m}^{-3}$ are still to be avoided entirely although exceptions are possible at concentrations between 2 and $4 \mathrm{mg} \mathrm{m}^{-3}$ for special flights such as search and rescue or research flights. Although, maximum ash concentrations in the vicinity of past aircraft encounters of class 4 were analyzed to exceed at least $4 \mathrm{mg} \mathrm{m}^{-3}$ with far higher concentration in the vicinity (Witham et al., 2012), the hazard of volcanic ash to aviation likely depends on more parameters than just the airborne ash mass concentration including the time spent in an ash layer, the engine type and the power setting. It may also vary between different eruptions (or even within a single eruption) because ash properties are not uniform.

Having in mind the safety criterion of "no flight in visible ash," a key question is whether a pilot has the means to avoid flying through potentially dangerous ash layers just by visual observation of the atmospheric situation out of the flight deck. The goal of this study is to assess whether it is possible from the pilot's perspective in flight to detect the presence of volcanic ash and to distinguish between volcanic ash and other aerosols ${ }^{2}$ by sight. We focus on volcanic ash and mineral dust, the two aerosol types which potentially impact aircraft operation. In this paper we contrast the occurrence of mineral dust and volcanic ash aerosol and discuss their respective microphysical and optical properties. We show how the appearance of volcanic ash plumes changes with distance from the emitting source and use radiative transfer simulations to investigate the visibility of such aerosol layers for clear-sky conditions. Based on those simulations we discuss the lowest concentrations at which a volcanic ash aerosol layer is still visible under idealized conditions and if a pilot en route can distinguish airborne volcanic ash with a concentration of $2 \mathrm{mg} \mathrm{m}^{-3}$ from mineral dust layers of the same concentration.

\section{Methods}

\subsection{Data basis}

To contrast the properties of volcanic ash and mineral dust in detail, we use data from three field experiments with the DLR research aircraft Falcon (a Dassault Falcon 20E twin engine jet aircraft). Table 1 gives an overview of the data used in this study: the mineral dust data were gathered within the framework of the Saharan Mineral Dust Experiment (SAMUM, Ansmann et al., 2011a; Heintzenberg, 2009). Within SAMUM, two field experiments were performed: SAMUM-1 (summer 2006, Morocco) focused on the microphysical, optical and radiative properties of fresh dust aerosol in the vertical column over the Sahara, while SAMUM-2 (winter 2008, Cape Verde Islands) concentrated on the

\footnotetext{
${ }^{2}$ Aerosols here denote the two-phase system of particles suspended in air originating either from direct particle emission or from the conversion of gases to particles (e.g., Hinds, 1999).
} 
Table 1

Data basis for this study. A detailed description of the instruments, data quality and uncertainties is given in the publication denoted in the last column of this table.

\begin{tabular}{|c|c|c|c|c|c|}
\hline Field experiment & Falcon base & Time of measurements & Aerosol type & Aerosol age since emission & Related publication \\
\hline SAMUM-1 & Casablanca (Morocco) & 18 May - 7 Jun 2006 & Fresh mineral dust & $<2$ days & Weinzierl et al. (2009) \\
\hline SAMUM-2 & Praia (Cape Verde) & 19 Jan - 9 Feb 2008 & Aged mineral dust & $1-5$ days & Weinzierl et al. (2011) \\
\hline Eyjafjalla volcano & Oberpfaffenhofen (Germany) & 19 Apr - 18 May 2010 & Volcanic ash & 7 hours -5 days & Schumann et al. (2011) \\
\hline
\end{tabular}

microphysical and optical properties of aged dust and the mixing of dust with biomass burning aerosol. The volcanic ash data were collected between 19 April and 18 May 2010, when Icelands' Eyjafjalla volcano was active (Schumann et al., 2011).

Here we summarize only the most important aspects of the instrumentation and data analysis. An in-depth description of the instruments employed during the three flight missions including an assessment of measurement uncertainties and limitations is given in Weinzierl et al. (2009, 2011) and Schumann et al. (2011). The instrumentation of the Falcon was very similar for the two mineral dust missions; a slightly different instrumentation was used for the volcanic ash measurements. Table 2 summarizes the instrumentation during the three field missions. In all cases, meteorological parameters like temperature, pressure, relative humidity and wind velocity were recorded with the Falcon standard instrumentation. The main difference in the instrumentation was the deployment of a combined aerosol and trace gas instrumentation including measurements of $\mathrm{SO}_{2}, \mathrm{O}_{3}$, and $\mathrm{CO}$ during the volcanic ash flights whereas only aerosol parameters were measured during SAMUM-1 and SAMUM-2. Furthermore, different lidar systems were used for the mineral dust and the volcanic ash flights: a 2- $\mu \mathrm{m}$ Doppler wind lidar (Weissmann et al., 2005) was deployed during the volcanic ash missions whereas a nadir-looking High Spectral Resolution Lidar (HSRL, Esselborn et al., 2009) was used during the two SAMUM field experiments. The wind lidar data provide an accurate determination of the vertical and horizontal wind speed and give insight into the vertical aerosol layering of the atmosphere. The instrument turned out to be very sensitive to vol- canic ash and allows the derivation of the lower and upper boundaries of the aerosol layers with a vertical resolution of $100 \mathrm{~m}$. As a result of the range resolution of the lidar $( \pm 50 \mathrm{~m})$ and the applied threshold on the signal strength and gradient $( \pm 100 \mathrm{~m})$, the uncertainty in the determination of the upper and lower boundaries of the volcanic ash layers is $\pm 150 \mathrm{~m}$ (Schumann et al., 2011). In contrast to the wind lidar, the HSRL allows for the direct measurement of aerosol optical properties such as extinction coefficient, backscatter coefficient, lidar ratio, linear particle depolarization ratio and water vapor, however, it does not provide information about the vertical and horizontal wind speed. During all three missions, the lidars acted as pathfinders to direct the aircraft into the mineral dust and volcanic ash layers for representative in situ measurements. In the case of the volcanic ash measurements the lidar was important for safety concerns: based on the lidar signal, the Falcon crew decided whether it was safe to fly into an ash cloud or not. To acquire a statistically adequate amount of data for the analysis of size distributions in a plume, time sequences of 510 min duration at a constant altitude were performed in the aerosol layers at different altitudes. Depending on the Falcon ground speed, 5-10 min of flight time correspond to a horizontal distance of $90-120 \mathrm{~km}$.

In contrast to the lidar systems, the aerosol in situ instrumentation was rather similar during all field experiments: in all cases, the in situ instrumentation covered the size range of airborne aerosols from small nucleation mode particles with diameters, $D_{p}$, of several nanometers up into the far super-micron size range. The sub-micron aerosol was sized by 4-6 Condensation Particle Counters

Table 2

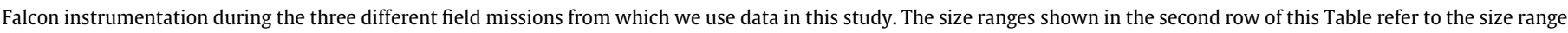
covered by the combination of the individual instruments during each of the three field experiments.

\begin{tabular}{|c|c|c|c|}
\hline Quantity & SAMUM-1 (2006) & SAMUM-2 (2008) & Eyjafjalla volcano (2010) \\
\hline Aerosol size distribution (nucleation mode-coarse mode) & $4 \mathrm{~nm}-100 \mu \mathrm{m}$ & $4 \mathrm{~nm}-30 \mu \mathrm{m}$ & $4 \mathrm{~nm}-800 \mu \mathrm{m}$ \\
\hline Several condensation particle counters (CPC) operated at different lower cut-off diameters & $\times$ & $\times$ & $\times$ \\
\hline Differential Mobility Analyzer (DMA) & $\times$ & $\times$ & - \\
\hline Optical Particle Counter, type Grimm SKY-OPC 1.129 (Grimm OPC) & - & - & $\times$ \\
\hline Passive Cavity Aerosol Spectrometer Probe (PCASP-100X) & $\times$ & $\times$ & $\times$ \\
\hline Forward Scattering Spectrometer Probe (FSSP-300) & $\times$ & $\times$ & $\times$ \\
\hline Forward Scattering Spectrometer Probe (FSSP-100) & $\times$ & - & - \\
\hline Two-dimensional imaging cloud probe (2D-C) & - & - & $\times$ \\
\hline \multicolumn{4}{|l|}{ Measurement of the absorption coefficient and the particle volatility $\left(D_{p}<2.5 \mu \mathrm{m}\right)$} \\
\hline Single-wavelength Particle Soot Absorption Photometer (1- $\lambda$-PSAP) & - & $\times$ & - \\
\hline Three-wavelength Particle Soot Absorption Photometer (3- $\lambda$-PSAP) & $\times$ & $\times$ & $x$ \\
\hline Heated $\left(250^{\circ} \mathrm{C}\right) \mathrm{CPC}$ & $\times$ & $\times$ & $\times$ \\
\hline Heated $\left(250^{\circ} \mathrm{C}\right) \mathrm{DMA}$ & $\times$ & $\times$ & - \\
\hline Heated $\left(250^{\circ} \mathrm{C}\right)$ Grimm OPC & $\times$ & $\times$ & $\times$ \\
\hline \multicolumn{4}{|l|}{ Particle sampling for post-flight chemical composition and shape analyses } \\
\hline Impactor sampling $\left(D_{p}<2.5 \mu \mathrm{m}\right)$ & $\times$ & $\times$ & $\times$ \\
\hline Giant Particle Collector (GPaC) & - & $\times$ & $\times$ \\
\hline \multicolumn{4}{|l|}{ Trace gases measurements } \\
\hline $\mathrm{SO}_{2}$ & - & - & $\times$ \\
\hline $\mathrm{CO}$ & - & - & $\times$ \\
\hline $\mathrm{O}_{3}$ & - & - & $\times$ \\
\hline \multicolumn{4}{|l|}{ Lidar measurements } \\
\hline High Spectral Resolution Lidar (HSRL) & $\times$ & $\times$ & - \\
\hline 2- $\mu \mathrm{m}$ Doppler wind lidar & - & - & $\times$ \\
\hline \multicolumn{4}{|l|}{ Meteorological measurements } \\
\hline Falcon standard instrumentation (position, temperature, pressure, humidity, wind) & $\times$ & $\times$ & $\times$ \\
\hline
\end{tabular}


(CPCs) operated at different cut-off diameters, a Differential Mobility Analyzer (DMA) operated in a stepping mode, and by an Optical Particle Counter type Grimm SKY-OPC 1.129 (Grimm OPC). Moreover, instruments for the measurement of the absorption coefficient and the determination of the size distribution of nonvolatile aerosol compounds were available: the absorption coefficient was measured with a single- (SAMUM-2) and a multi-wavelength (SAMUM-1, SAMUM-2, Eyjafjalla) Particle Soot Absorption Photometer (PSAP). We used the data from the multi-wavelength PSAP instrument to invert the complex refractive index following a method described in detail in Petzold et al. (2009, 2011). With this inversion method, the PSAP response at the three wavelengths was simulated using the CPC, PCASP and Grimm OPC size distribution measurements and an assumption of a complex refractive index. The complex refractive index was then optimized in an iterative process to match the PSAP's responses at all three wavelengths within a deviation of $3 \%$.

The non-volatile aerosol size distribution was determined by operating aerosol sizing instruments downstream of a thermal denuder heating the aerosol to $250^{\circ} \mathrm{C}$. Heating the aerosol to $250{ }^{\circ} \mathrm{C}$ provides insight into the aerosol mixing state (Clarke, 1991). More detail on the derivation of the aerosol mixing state using a thermal denuder is given in Weinzierl et al. (2009). The CPCs, DMA, the Grimm OPCs, and the PSAP were operated inside the cabin of the Falcon, sampling air from a nearly isokinetic inlet. The cut-off diameter at which $50 \%$ of the particles pass the isokinetic inlet is dependent on outside pressure and air speed. For typical Falcon speed, the inlet cut-off is near $2.5 \mu \mathrm{m}$ at ground level and decreases to about $1.5 \mu \mathrm{m}$ in the upper troposphere (Fiebig, 2001; Wendisch et al., 2004). In order to measure the super-micron particle fraction, several wing-mounted optical particle counters of type PMS Passive Cavity Aerosol Spectrometer Probe (PCASP-100X) and Forward Scattering Spectrometer Probe (FSSP-300, FSSP-100) were used. For the volcanic ash missions, the two-dimensional imaging cloud probe (2D-C) was additionally available covering the size range from about $25 \mu \mathrm{m}$ up to $800 \mu \mathrm{m}$. The PCASP-100X, the FSSP-300, and the FSSP- 100 cover different size ranges as a result of differences in optical measurement geometry and electronic signal processing. According to the manufacturers, the PCASP-100X covers nominally the size range between 0.12 and $3.5 \mu \mathrm{m}$, the FSSP-300 the size range between 0.3 and $30 \mu \mathrm{m}$, and the FSSP100 the size range between 5 and $95 \mu \mathrm{m}$. The actual size range of the optical particle counters depends critically on the refractive index of the particles passing through the instrument. For absorbing particles, the size range of the FSSP-300, for example, shifts towards larger sizes. For more detail on this see Weinzierl et al. (2009, 2011), Schumann et al. (2011), and Turnbull et al. (2012). We want to emphasize that the refractive index can vary over the entire size range or even for each individual particle in an aerosol. For example, we know from the analysis of single dust particles collected with the GPaC instrument and at the ground (Kandler et al., 2011; Lieke et al., 2011) that the mineral dust refractive index is strongly size dependent with super-micrometer particles showing almost zero absorption. To constrain the refractive index uncertainty for the derivation of size distributions in this study, we used the values for the refractive indices published in Weinzierl et al. (2011) for mineral dust (sub-micron size range: $1.55+0.001 i$; super-micron size range: $1.55+0 i)$, and Schumann et al. (2011) for volcanic ash (entire size range: $1.59+0.004 i$ ).

The derivation of size distributions from optical particle counters is not only sensitive to the refractive index, it may also be sensitive to the particle shape. Schumann et al. (2011) investigated the impact of particle non-sphericity on the instrument response of the FSSP-300 by applying T-matrix calculations. Their results demonstrate that the sizing of the FSSP-300 is more critically dependent on the refractive index than on particle shape.

\subsection{Radiative transfer calculations}

To systematically investigate the visibility of volcanic ash, we performed radiative transfer simulations using the Monte Carlo code for the physically correct tracing of photons in cloudy atmospheres, MYSTIC (Buras and Mayer, 2011; Emde et al., 2010; Emde and Mayer, 2007; Mayer, 2009). MYSTIC traces individual photons on their paths through the atmosphere, taking into account scattering and absorption by molecules, water droplets, ice particles and aerosols, and the reflection at the Earth's surface. MYSTIC allows exact calculation of radiances without simplifying assumptions and has been validated in a number of model intercomparisons and through comparison with observations. For the simulation of the visible images in this study, spectral radiances were calculated between 380 and $780 \mathrm{~nm}$, weighted with the sensitivity of the human eye for red, green, and blue, integrated over wavelength, and converted to an RGB image which can be compared to a photograph. For the simulation of the pilot's view, photons were traced backwards (from the eye to the sun), which enhances performance considerably.

MYSTIC is operated in the framework of the libRadtran radiative transfer package (Mayer and Kylling, 2005), which provides the optical (scattering and absorption) properties of the atmosphere. Temperature, pressure, and atmospheric trace gases were taken from the mid-latitude summer atmosphere by Anderson et al. (1986). The optical properties and scattering phase functions of the aerosols were computed following the approach by Gasteiger et al. (2011), but using the size distribution and wavelengthdependent refractive indices from the in situ measurements described in the previous section. In this approach, the optical properties of single particles are calculated using the T-matrix method and geometric optics; subsequently, the optical properties are averaged over the size and shape distribution. Here the particles are assumed to have spheroidal shapes (Gasteiger et al., 2011; Mishchenko and Travis, 1998). The aspect ratio distribution of the volcanic ash particles was inferred from lidar measurements taken in Munich (Maisach) during the Eyjafjalla eruption on 17 April 2010 (Gasteiger et al., 2011). The median aspect ratio is close to 2.0, which is in the same range as found by microscopic analyses of particles from the Eyjafjalla plume (Schumann et al., 2011). The aspect ratio distribution of mineral dust is based on microscopic analyses of Saharan mineral dust during the SAMUM-1 campaign by Kandler et al. (2009). The median aspect ratio of Saharan mineral dust is approximately 1.6 .

\section{Properties of volcanic ash and mineral dust aerosols}

\subsection{Occurrence of mineral dust and volcanic ash particles}

The atmospheric occurrence of volcanic ash and mineral dust differs due to different source locations and different mobilization mechanisms. The characteristics of volcanic ash and mineral dust layers are outlined below and summarized in Table 3.

\subsubsection{Volcanic ash}

Volcanic ash accounts for only about $1 \%$ of the annual global emitted particle mass (Hinds, 1999). About 1500 active volcanoes are known worldwide, and on average, globally 50-70 volcanoes erupt every year (Siebert et al., 2010). The Pacific region, specifically the so-called "ring of fire", represents the area with the largest concentration of active volcanoes on Earth showing explosive activity. Within Europe, Iceland shows the highest density of active volcanoes with presently more than 30 . Two of them (Eyjafjalla and Grimsvötn) erupted in April/May 2010 and May 2011, respectively. In this study, we concentrate on the emissions of Eyjafjalla 
Table 3

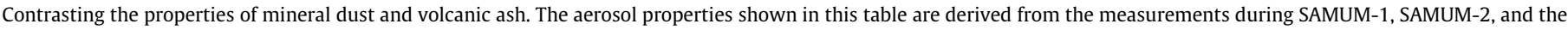
Eyjafjalla volcanic ash missions. The microphysical and optical properties of volcanic ash may be different for a different volcano.

\begin{tabular}{|c|c|c|}
\hline Parameter & Saharan mineral dust & Eyjafjalla volcanic ash \\
\hline $\begin{array}{l}\text { Mobilization mechanism for } \\
\text { super-micrometer particles }\end{array}$ & Wind speed at the ground exceeds a certain limit & Explosive eruption \\
\hline Altitude range & $\begin{array}{l}\text { Mainly troposphere (below } 6 \mathrm{~km} \text { at the dust source region; } \\
\text { mainly below } 8 \mathrm{~km} \text { far away from the source) }\end{array}$ & $\begin{array}{l}\text { Mainly troposphere (below } 10 \mathrm{~km} \text {, Eyjafjalla volcano); troposphere } \\
\text { and stratosphere (up to } 30 \mathrm{~km} \text {, other volcanoes) }\end{array}$ \\
\hline Plume thickness & $0.1-6 \mathrm{~km}$ & $0.1-3 \mathrm{~km}$ \\
\hline Plume width & $100-1000 \mathrm{~km}$ & $10-500 \mathrm{~km}$ \\
\hline Volume size distribution & Mono-modal & Bi-modal \\
\hline $\begin{array}{l}\text { Maximal observed diameter in } \\
\text { elevated layers }\end{array}$ & $\begin{array}{l}<50 \mu \mathrm{m} \text { (close to the source), }<30 \mu \mathrm{m} \text { (at a distance of several } \\
100 \mathrm{~km} \text { away from the source) }\end{array}$ & $<30 \mu \mathrm{m}$ (at a distance of $400 \mathrm{~km}$ away from the volcano) \\
\hline Effective diameter, $D_{\text {eff }}$ & 2.5 (aged dust) $-6 \mu \mathrm{m}$ (fresh dust) & $0.2-10 \mu \mathrm{m}$ (including Aitken mode) \\
\hline Particle shape, aspect ratio & Aspherical particles, median aspect ratio 1.6 & Aspherical particles, median aspect ratio 2.0 \\
\hline Main composition & Quartz, hematite and clay minerals & $40-75 \%$ siliciumdioxid \\
\hline Petrology & Crystalline & Glassy or crystalline \\
\hline Melting temperature & $\sim 1650{ }^{\circ} \mathrm{C}$ for pure quartz & Softening of the Eyjafjalla volcanic ash starts at $\sim 700^{\circ} \mathrm{C}$ \\
\hline $\begin{array}{l}\text { Typical refractive index } \\
\quad(550 \mathrm{~nm}) \text {, real part }\end{array}$ & $1.55 \pm 0.2$ & $1.58 \pm 0.2$ \\
\hline $\begin{array}{l}\text { Typical refractive index } \\
(550 \mathrm{~nm}) \text {, imaginary part }\end{array}$ & $0.001-0.004$ & $0.002-0.015$ \\
\hline $\begin{array}{l}\text { Ångström exponent of } \\
\text { absorption }(467-660 \mathrm{~nm})\end{array}$ & $2-6$ & $1-3$ \\
\hline Optical appearance & Yellow to brownish & Dark gray to brownish \\
\hline Area of impact & Dust storms close to airports; affects take-off and landing & $\begin{array}{l}\text { Free troposphere; affects aircraft at cruising altitude, take-off and } \\
\text { landing }\end{array}$ \\
\hline
\end{tabular}

because we do not have airborne data from the eruption of the Grimsvötn.

Volcanic eruptions last from several seconds up to several months in general producing inhomogeneous ash plumes. The eruption of Eyjafjalla lasted roughly 6 weeks, separated in two phases with significantly different eruptive behavior (Sigmundsson et al., 2010). Not surprisingly, the ash emission rate was highly variable during the entire eruption. During the second, more explosive phase from within the summit caldera (14 April through 21 May 2010), Eyjafjalla ejected thick ash plumes into the troposphere, reaching heights up to $10 \mathrm{~km}$ a.s.l. (Heinold et al., 2011; Stohl et al., 2011). Fig. 1a shows lidar cross-sections of the Eyjafjalla volcanic ash plume on 2 May 2010. On this day, the plume had a vertical thickness of about $2 \mathrm{~km}$ and a horizontal width of about $11 \mathrm{~km}$ (perpendicular to the direction of propagation) close to the volcano. It can be seen that the ash plume close to the volcano in Iceland has sharp edges, but the internal structure of the plume is very inhomogeneous.

Although the Eyjafjalla eruption strongly impacted aviation in Europe, this eruption was a medium-size event compared to other historical eruptions (e.g., Mt. St. Helens or Pinatubo) in terms of eruption column height or erupted volumes. For comparison, it is not uncommon for other volcanoes to have ash plume columns rising up to altitudes of up to $30 \mathrm{~km}$ (e.g., Casadevall, 1993; Newhall and Self, 1982). The ash plume of Eyjafjalla reached large parts of Europe and even if not visible everywhere to the human eye, the DLR Falcon aircraft observed it over Germany, Poland, Denmark, the Netherlands, Norway, the North Sea, Great Britain, and in the vicinity of the volcano at altitudes between 0.4 and $7 \mathrm{~km}$ a.s.l. Mass concentrations measured by the Falcon ranged between 0.01 and $0.8 \mathrm{mg} \mathrm{m}^{-3}$ (Schumann et al., 2011). Although plumes exceeding concentrations of $2 \mathrm{mg} \mathrm{m}^{-3}$ were clearly present, at least close to the volcano, the Falcon never entered plumes with such high concentrations. Over Germany, the maximum observed coarse mode aerosol optical depth (at $500 \mathrm{~nm}$ ) was between 1.0 and 1.2 (Ansmann et al., 2011b). In total, about $10 \mathrm{Tg}$ (best estimate with an uncertainty range of $2.5-50 \mathrm{Tg}$ depending on the aerosol refractive index assumed for the data analysis) of ash and about $3(0.6-23) \mathrm{Tg}$ of $\mathrm{SO}_{2}$ were introduced into the atmosphere from 14 April through 21 May 2010 (Schumann et al., 2011).
The Eyjafjalla volcanic ash aerosol was mainly composed of fragments of quenched silicate melt with microlites and subordinate lithic components (Kueppers et al., 2010). For the imaginary part of the aerosol refractive index at $550 \mathrm{~nm}$ values between 0.002 and 0.015 were derived with the PSAP inversion method. The geometrical thickness of the ash layers observed during the DLR Falcon research flights varied between $200 \mathrm{~m}$ and $3 \mathrm{~km}$. The ash plume had a horizontal width of about $10 \mathrm{~km}$ (perpendicular to the direction of propagation) close to the volcano reaching up to several hundred kilometers at larger distances downwind of the volcano. A quantitative ash dispersion modeling study by Stohl et al. (2011) estimated that during the Eyjafjalla eruption phase in April 2010, volcanic ash concentrations at some altitude in the atmosphere exceeded the limits of 0.2 and $2 \mathrm{mg} \mathrm{m}^{-3}$ in up to $14 \%$ and $1.5 \%$ of the European area, respectively, while a concentration of $4 \mathrm{mg} \mathrm{m}^{-3}$ was rarely reached.

\subsubsection{Mineral dust}

Mineral dust contributes to about half of the global annual particle emissions by mass (Hinds, 1999). The largest and most persistent sources of mineral dust are located in an area extending from the west coast of North Africa, over the Middle East, Central and South Asia, to China (Prospero et al., 2002). The Southern Hemisphere is free of major dust activity (Prospero et al., 2002). With an area of 9 million $\mathrm{km}^{2}$, the Sahara is the largest desert on Earth and releases about $50-70 \%$ of the annual global dust emissions (Mahowald et al., 2005). The dust is lifted by strong winds resulting either from synoptic-scale cyclones in the northern sector of the Sahara, harmattan surges and African easterly waves, low-level jets and cold pools from meso-scale convective systems (particularly over the Sahel), or micro-scale dust devils and dusty plumes (Knippertz and Todd, 2012). Once in the air, dust can be transported over several thousands of kilometers, reaching Europe, Northern America or the Caribbean (Colarco et al., 2003; Huang et al., 2010; Mattis et al., 2008; Moulin and Chiapello, 2006; Müller et al., 2003). In the dust source region, the dust is spread over the entire boundary layer. During SAMUM-1 in the summer of 2006, we observed the dust-laden boundary layer to reach a vertical depth of up to 5-6 km above ground level. When the airborne dust is advected with the wind across mountains or from land to the sea 


\section{(a) 2 May 2010: Iceland - Scotland}

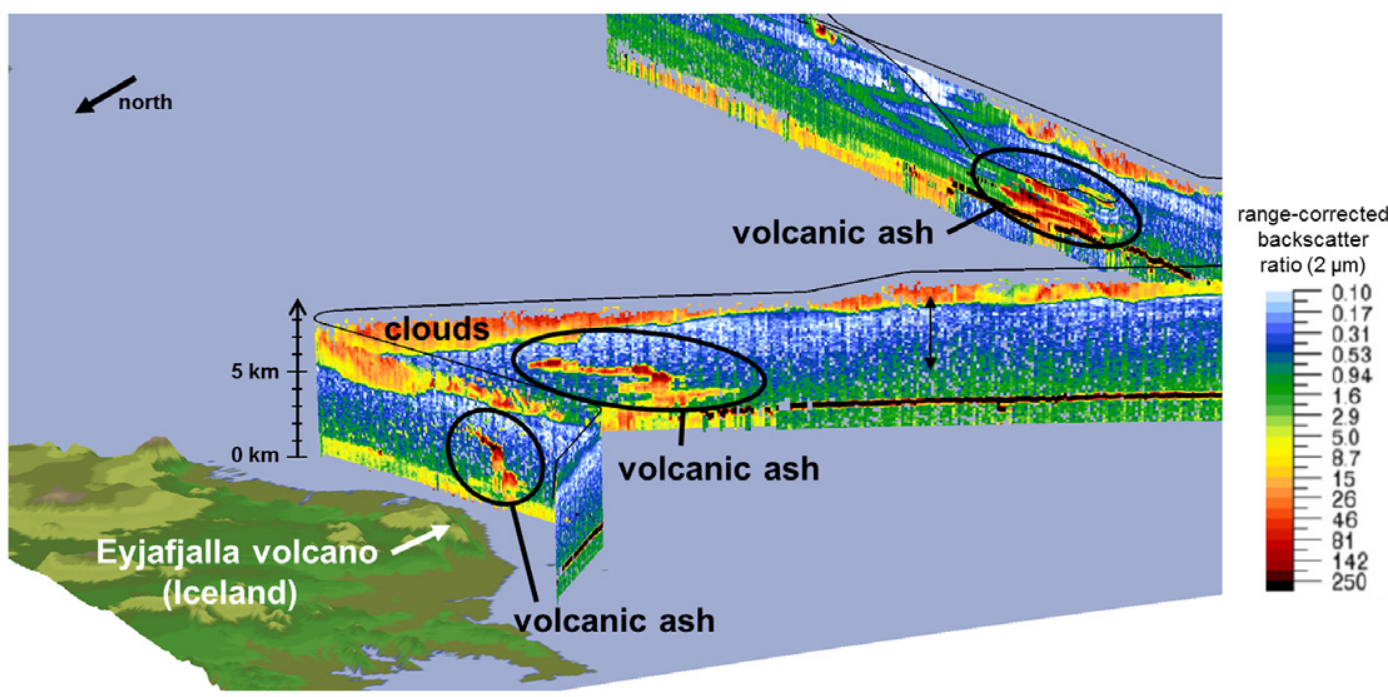

(b) 3 June 2006: Casablanca - Zagora

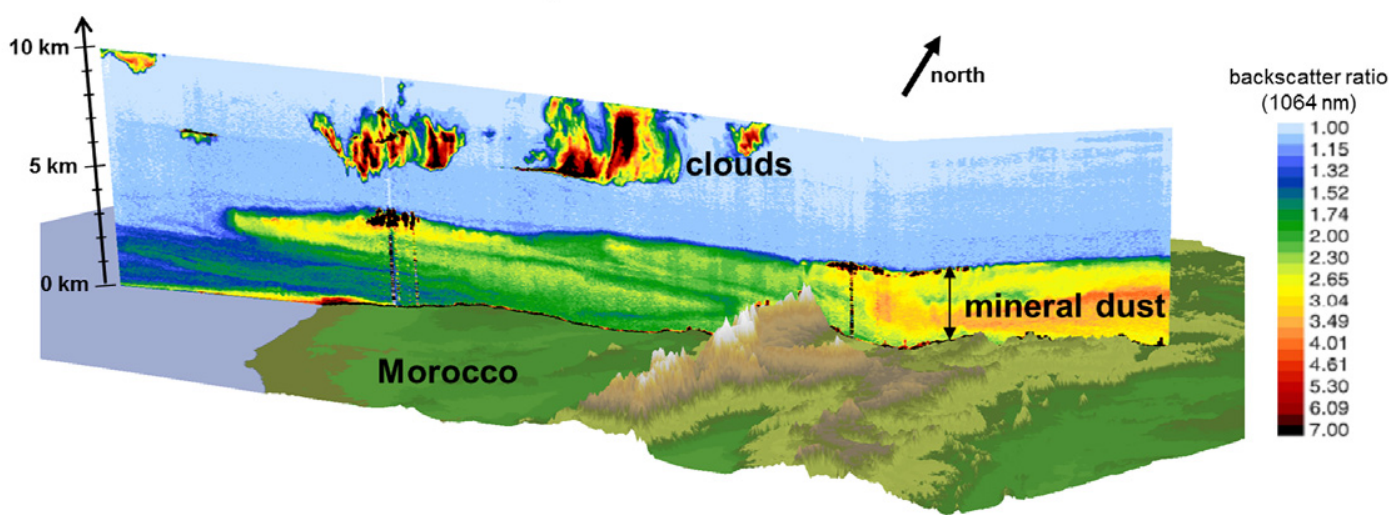

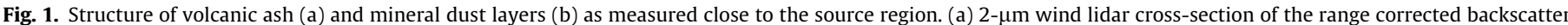

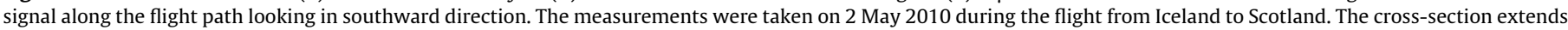

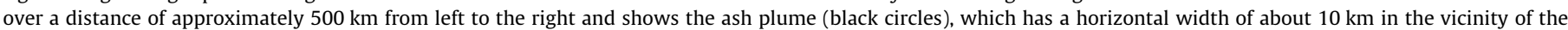

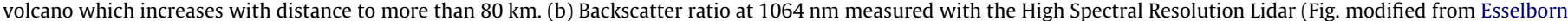

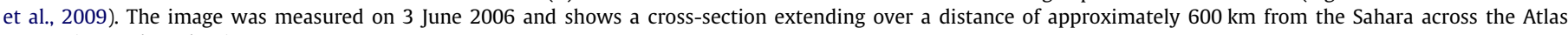
Mountains to the Atlantic Ocean.

over cool oceanic air, elevated dust layers with a very homogeneous internal structure are formed (Fig. 1b). The elevated dust layers can be as deep as $5 \mathrm{~km}$, and the plume top heights measured during SAMUM-1 and SAMUM-2 were mainly below $6 \mathrm{~km}$ a.s.l. Similar findings were obtained from 10 years of mineral dust observations (1997-2006) above Leipzig (Mattis et al., 2008): in about $80 \%$ of the cases, the observed mineral dust was below $6 \mathrm{~km}$ a.s.l., and in more than $90 \%$ of the cases, the layers were below $8 \mathrm{~km}$ a.s.l.

Kandler et al. (2009) report as major constituents of Saharan mineral dust the components quartz, potassium feldspar, plagioclase, calcite, hematite and the clay minerals illite, kaolinite and chlorite. The imaginary part of the refractive index of mineral dust derived from the PSAP data, ranged between 0.001 and 0.004 (at $550 \mathrm{~nm}$ ), while the real part of the refractive index was found to be nearly constant with values between 1.55 and 1.56 (Petzold et al., 2009; Weinzierl et al., 2011). In our SAMUM measurements, the median dust mass concentration was $0.9 \mathrm{mg} \mathrm{m}^{-3}$ (3rd and $97 \mathrm{th}$ percentile: $p_{03}=0.1 \mathrm{mg} \mathrm{m}^{-3} ; p_{97}=3.3 \mathrm{mg} \mathrm{m}^{-3}$ ) close to the Sahara, and $0.3 \mathrm{mg} \mathrm{m}^{-3}\left(p_{03}=0.03 \mathrm{mg} \mathrm{m}^{-3} ; p_{97}=1.4 \mathrm{mg} \mathrm{m}^{-3}\right)$ in the Cape Verde region. The corresponding dust-related AOD at $532 \mathrm{~nm}$ var- ied between 0.03 and 0.7 (Weinzierl et al., 2011). These values are in agreement with simulations of the regional dust model system COSMO-MUSCAT (Heinold et al., 2009), which consists of the COSMO model of the DWD (German Weather Service) as meteorological driver, and the online-coupled three-dimensional chemistry tracer transport model MUltiScale Chemistry Aerosol Transport Model (MUSCAT). The model computes dust emissions in non-vegetated areas depending on surface wind friction velocities, surface roughness, soil particle size distribution, and soil moisture, where surface wind and soil moisture fields are assimilated from the meteorological model COSMO. The MUSCAT tracer scheme transports dust as a passive tracer in five independent size bins. Fig. 2 shows a map with the Saharan dust distribution for the entire year 2007, computed at a horizontal grid resolution of $28 \mathrm{~km}$ with 40 vertical layers. For each model grid cell the number of days was computed on which the dust concentration exceeded the given limit $\left(0.2,2\right.$, and $\left.4 \mathrm{mg} \mathrm{m}^{-3}\right)$ at any height. For large parts of the Saharan desert the limit of $0.2 \mathrm{mg} \mathrm{m}^{-3}$ is exceeded by the presence of Saharan dust for at least 18 days per year. Values of $2 \mathrm{mg} \mathrm{m}^{-3}$ are exceeded mainly between December and April in regions around Algeria, Libya, Niger and Chad. 


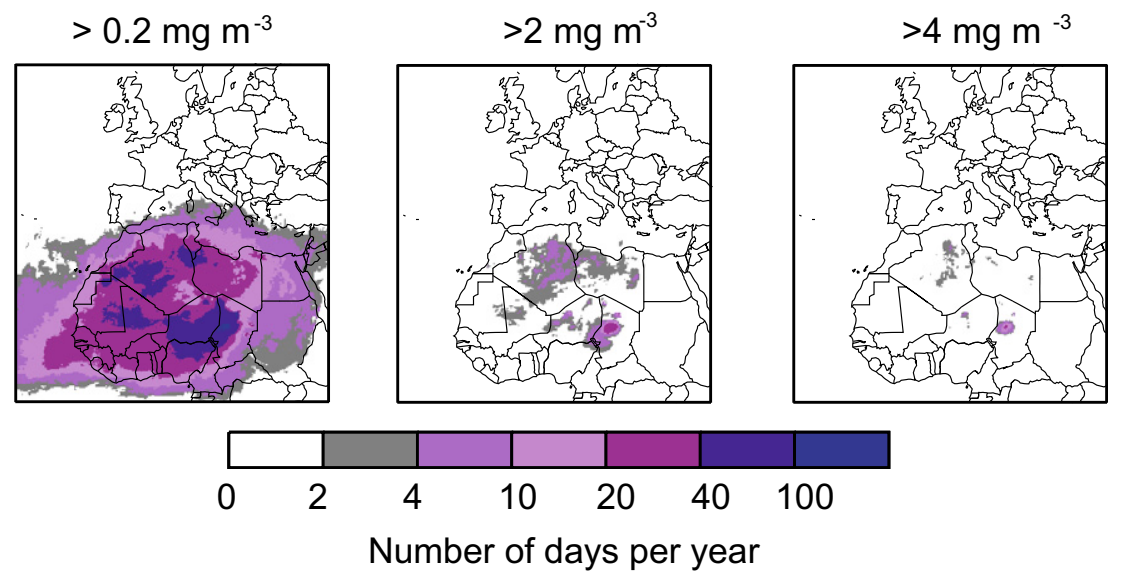

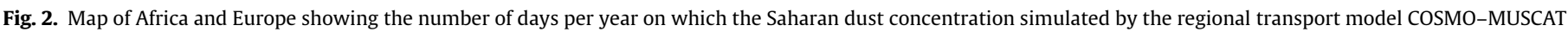
exceeded the given limit at any height.

To our knowledge, in contrast to the current policy regarding volcanic ash, safety limits for aircraft operation in dusty areas have not been established. However, it is known that aircraft engines which regularly fly in areas with high mineral dust loads tend to age faster than scheduled, and often require unscheduled maintenance and/or premature overhaul (W. Schneider, DLR flight experiments, personal communication).

\subsection{Comparing microphysical and optical properties of mineral dust and volcanic ash}

Although, the aerosol mobilization mechanism for mineral dust and volcanic ash is different, a comparison of microphysical and optical properties of both aerosol types shows similarities. Fig. 3 depicts particle volume size distributions ${ }^{3}$ of Eyjafjalla volcanic ash and Saharan mineral dust. The size distributions were derived from the combined analysis of three CPCs, a PCASP-100X, FSSP-300 with the assumptions described in Section 2.1. The volcanic ash aerosol shows a bi-modal volume size distribution whereas the mineral dust size distribution shows only one maximum. The volcanic ash aerosol does not only contain an enhanced coarse mode particle population, but also sulfuric acid droplets and/or sulfate particles of sizes smaller than about $150 \mathrm{~nm}$ (Schumann et al., 2011). Nevertheless, the optical properties of volcanic ash and mineral dust are relatively similar. Fig. 4 shows the wavelength-dependent real and imaginary parts of the refractive index inferred from the multiwavelength PSAP for mineral dust (dotted lines) and volcanic ash (solid lines). These refractive indices were used to derive the optical properties of aerosol layers for the radiative transfer calculations shown in Section 4. Overall, volcanic ash shows a larger imaginary part of the refractive index corresponding to stronger absorption than mineral dust. The wavelength-dependence of the absorption coefficient in both materials is different. For mineral dust the imaginary part of the refractive index drops by more than a factor of four between the blue and the red part of the spectrum, whereas for volcanic ash the drop is only of a factor of about two. Therefore dust will, in principle, appear more reddish than the volcanic ash. Another difference in optical properties originates from their different particle shapes, which affects mostly the polarization properties. Fig. 5 shows a comparison of the phase functions (i.e., the P11 components

\footnotetext{
3 The volume size distribution is the 3 rd moment of the particle count size distribution and describes the total volume occupied by particles having particle diameters between $D_{p}$ and $D_{p}+d D_{p}$ in $1 \mathrm{~cm}^{3}$ air. Assuming a particle density, the volume size distribution relates the mass of particulate matter to the diameters (see e.g., Hinds, 1999)
}
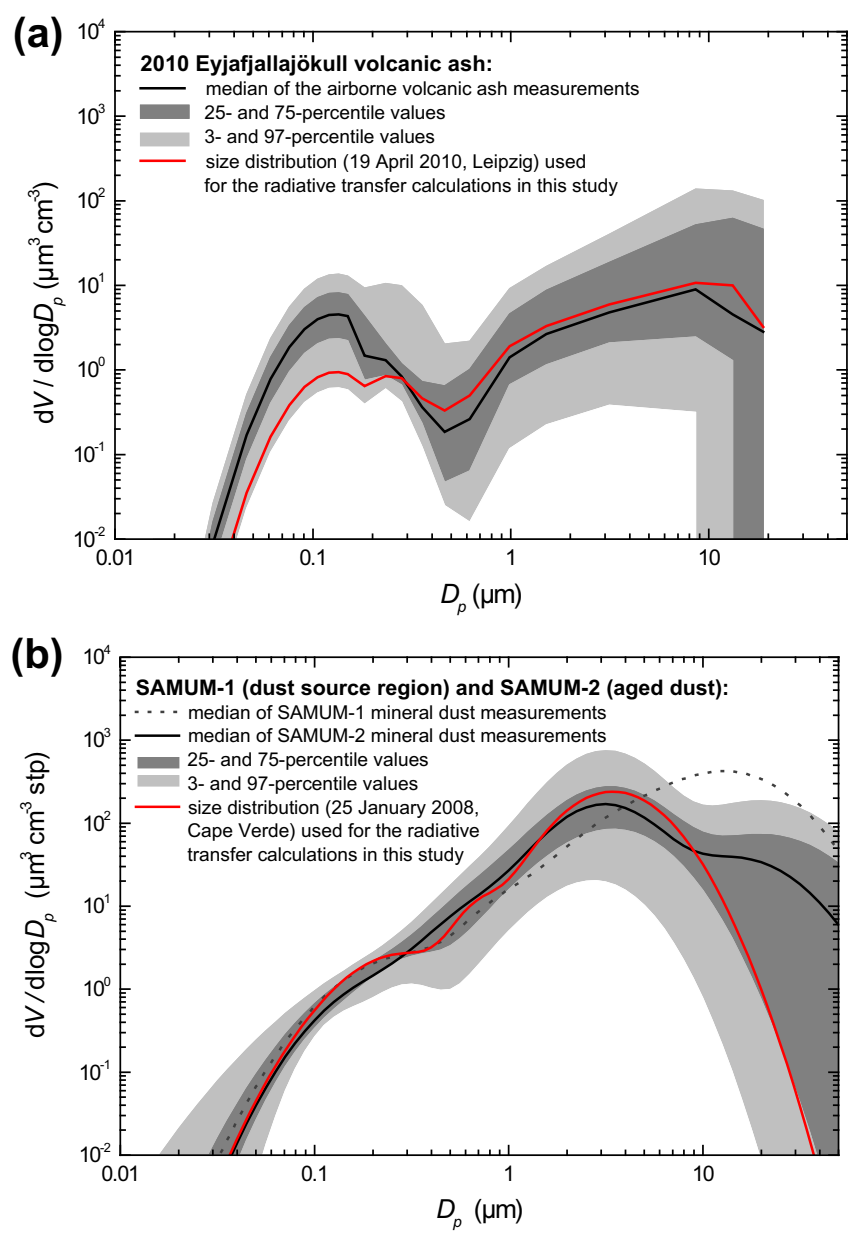

Fig. 3. Composite particle volume size distributions of Eyjafjalla volcanic ash (top panel) and Saharan mineral dust (bottom panel) derived from a set of Condensation Particle Counters (CPCs), a Passive Cavity Aerosol Spectrometer Probe (PCASP-100X), and a Forward Scattering Probe (FSSP-300). The dark and light gray shaded areas indicate the 3rd, 25th, 75th and 97th percentile values for all size distributions measured during the volcanic ash missions and the Saharan Mineral Dust Experiment, respectively. The red line indicates the size distributions used for the radiative transfer simulations performed in this study. (For interpretation of the references to color in this figure legend, the reader is referred to the web version of this paper.)

of the scattering phase matrix, see Section 2.2), which are a measure for the probability for photons to be scattered into a certain angular direction (see e.g., Emde et al., 2010, for details). The phase functions 


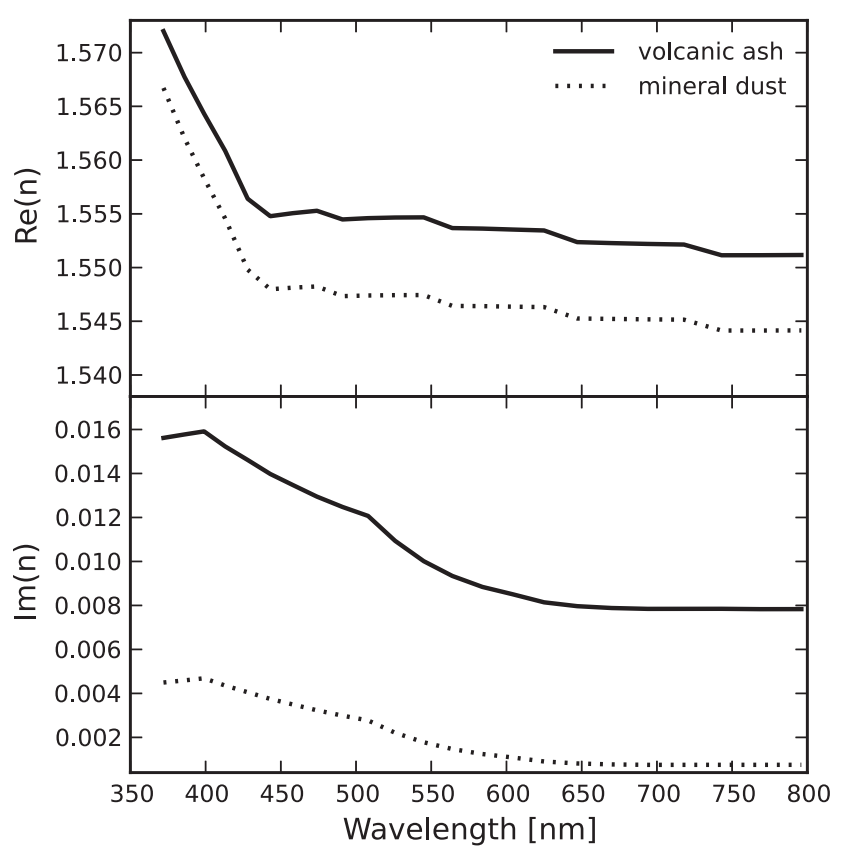

Fig. 4. Wavelength-dependent refractive index for volcanic ash and mineral dust used to determine the optical properties of the aerosol layers. The top panel shows the real part of the refractive index, and the bottom panel displays the imaginary part. Solid lines correspond to volcanic ash; dotted lines correspond to mineral dust. While the real parts of both refractive indices are similar, both aerosol types differ clearly in the imaginary part.

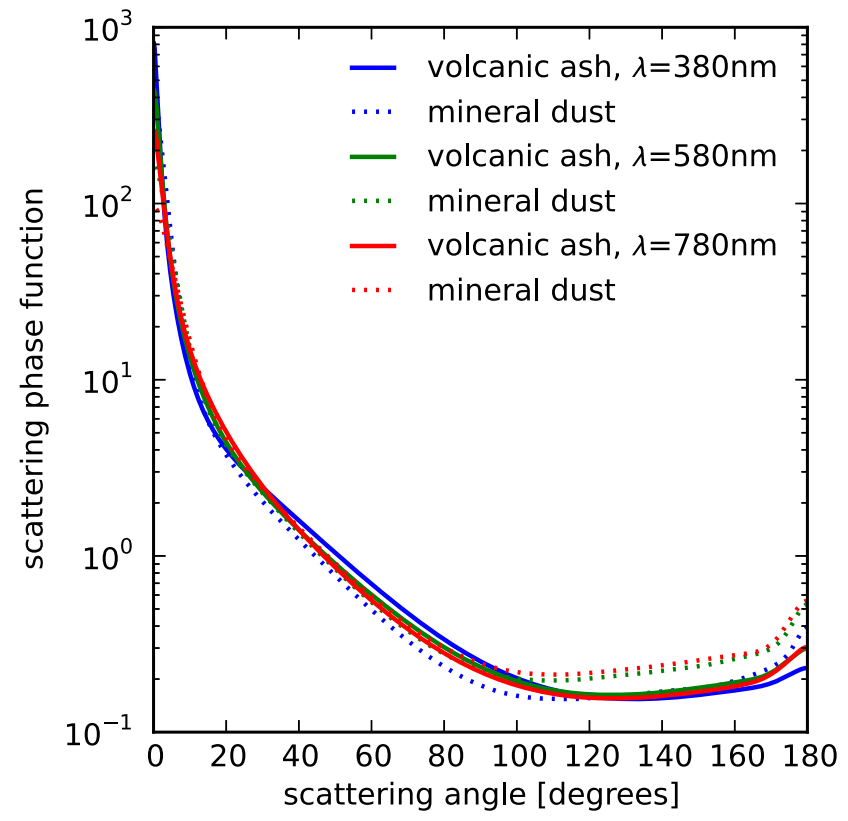

Fig. 5. Scattering phase functions (i.e., the P11 elements of the scattering phase matrix) used in the radiative transfer calculations. The solid lines correspond to the volcanic ash aerosol, dashed lines to mineral dust. The different colors correspond to the wavelengths $380 \mathrm{~nm}$ (blue), $580 \mathrm{~nm}$ (green) and $780 \mathrm{~nm}$ (red) (a-f). (For interpretation of the references to color in this figure legend, the reader is referred to the web version of this article.)

of the different aerosols types are relatively similar, although volcanic ash exhibits slightly stronger scattering in forward angles $\left(<90^{\circ}\right)$. In the backward direction $\left(>90^{\circ}\right)$ scattering of mineral dust particles is somewhat stronger, especially at longer wavelengths.

\section{Visibility of airborne volcanic ash}

In general, the question of whether a pilot can see an ash layer (or any other prominent aerosol layer ${ }^{4}$ ), that means, the visibility of airborne volcanic ash, depends on many parameters. The visibility of an object depends in particular on the brightness and color contrast between the object and the background (Koschmieder, 1925). A perfectly black object can be seen against the horizon, when the brightness contrast between the object and the background is larger than the contrast threshold of the human eye, for which a value of 0.02 is generally adopted (Horvath, 1971; Koschmieder, 1925). Essentially, this question of visibility of a black object at a distance can be attributed entirely to the light extinction properties of the air mass lying between the object and the observer. The question of the visibility of airborne volcanic ash, however, is far more complex, because neither the actual object of interest (i.e., the airborne volcanic ash) nor the background has a well-defined structure and color. The visual detectability depends on parameters such as the size/distance ratio and the brightness and color contrast between the airborne volcanic ash and the background. The contrast depends on parameters such as illumination, mass concentration, particle size distribution, wavelength-dependent light scattering and absorption by the ash. For example, a dark ash cloud may be detected because of attenuation of radiation from a radiation source (such as the sun) or also because of the loss of visibility of another object (such as the skyline of a city) behind the ash. In this case, the optical depth of the ash plume determines the attenuation of radiation through the ash. However, the optical depth alone is not sufficient to characterize visibility. The viewing angle $\vartheta$ with respect to the volcanic ash layer is more important. For example, if an observer looks at a volcanic ash layer under a sloped viewing angle, the optical depth along the line-of-sight is larger than the vertical optical depth of the ash layer, and therefore the volcanic ash layer is more likely to be visible.

Here, we will assess the visibility of volcanic ash from inspection of photographs taken during our volcanic ash research flights and mass concentrations measured during those flights. We complement this analysis with idealized radiative transfer simulations for a variety of selected viewing geometries. We will discuss the minimum concentration of volcanic ash to appear visible under cloud-free conditions in Section 4.2. The question if a potentially hazardous volcanic ash layer can be distinguished from layers of other aerosol types such as mineral dust is discussed in Section 4.3. For all our simulations, we used the optical properties derived from volcanic ash measured in the plume from the Eyjafjalla eruption on 19 April 2010 over Leipzig, Germany. Using the size distributions measured with the British research aircraft FAAM (Facility for Airborne Atmospheric Measurements; Turnbull et al., 2012), leads to similar conclusions. The model runs for mineral dust were performed using typical Saharan mineral dust aerosol measured during the SAMUM-2 field mission on 25 January 2008 over Cape Verde (see also Figs. 3 and 4).

\subsection{Can a pilot see airborne volcanic ash?}

Fig. 6 shows six photographs of the Eyjafjalla volcanic ash plume taken with a Canon EOS 400D digital camera from onboard of the Falcon at different plume ages and under different meteorological conditions. Fig. 6a and b shows two pictures taken on 1 May 2010 close to the volcano. At a distance of $70 \mathrm{~km}$ southeast from the volcano (Fig. 6b) our lidar measurements showed that the ash cloud had a vertical thickness of about $2 \mathrm{~km}$ and a horizontal width of about $11 \mathrm{~km}$. The ash plume shows very sharp and well-defined edges. At a distance of about $200 \mathrm{~km}$ downstream from the volcano,

\footnotetext{
${ }^{4}$ In the following we will only refer to volcanic ash. However, the visibility considerations also apply to any other aerosol type.
} 
(a)

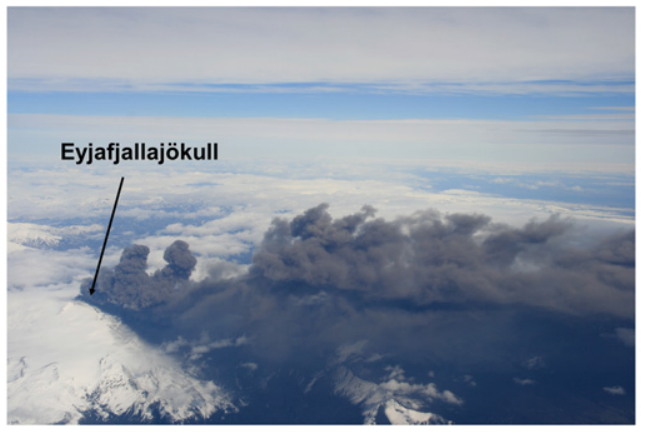

(c)

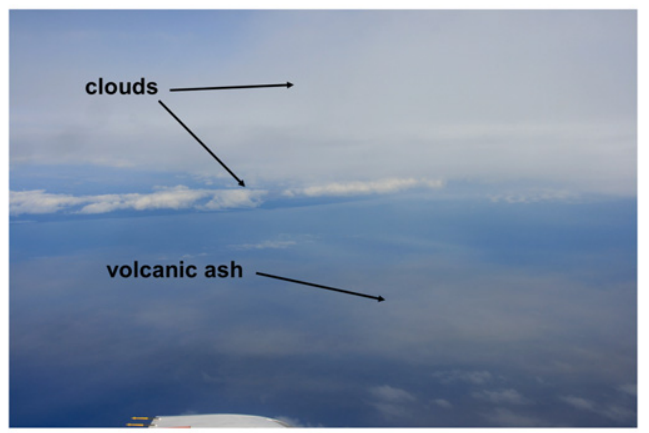

(e)

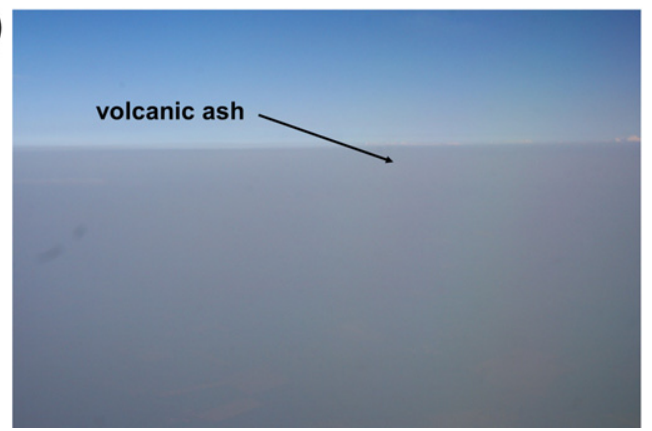

(b)

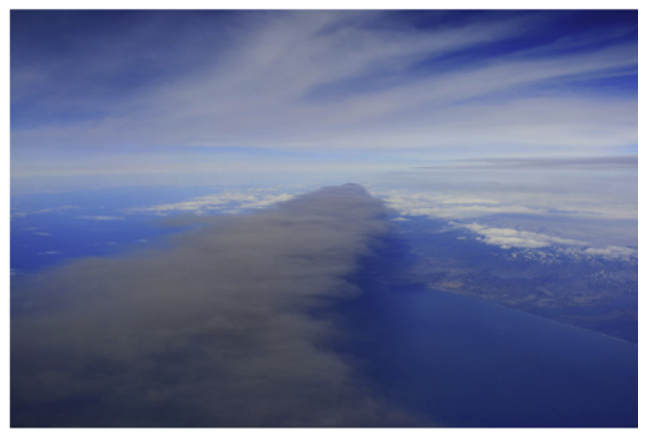

(d)

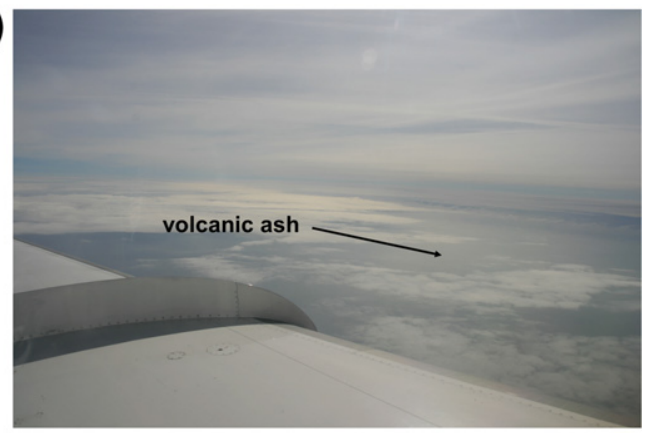

(f)

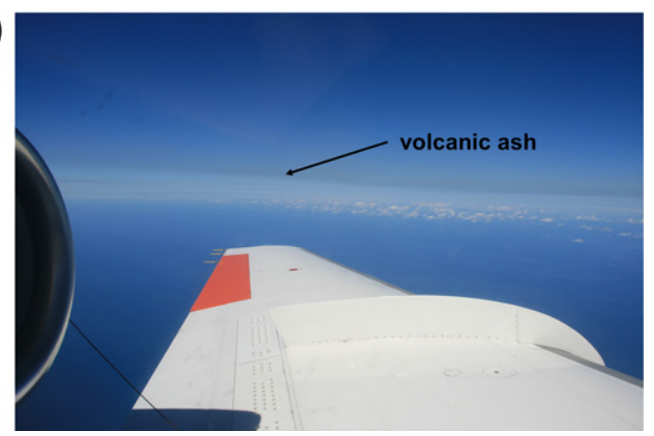

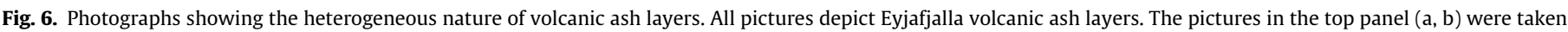

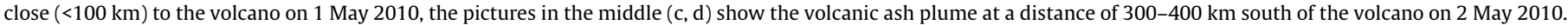

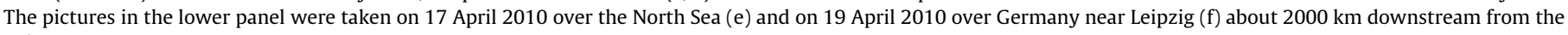
volcano.

the horizontal width of the ash layer extended to $30 \mathrm{~km}$, but the edges are still fairly sharp. In both cases (Fig. 6a and b), the ash is easy to distinguish from the background air because the brightness contrast between the blue sky and the grayish-brownish ash layer is high. Furthermore, regular water or ice clouds, which could hide the volcanic ash, are absent. Fig. $6 \mathrm{c}$ and $\mathrm{d}$ show the volcanic ash plume surrounded by clouds taken on 2 May 2010. Although, the mass concentrations are higher than $0.5-1.0 \mathrm{mg} \mathrm{m}^{-3}$ it is difficult to distinguish the volcanic ash from clouds. Fig. 6e and f show the volcanic ash plume $1700 \mathrm{~km}$ and $2400 \mathrm{~km}$ downstream of the volcano. In both cases, a wide-stretched ash layer with blurry edges is visible. Fig. 6e is a good example where the volcanic ash layer is visible because it reduces the brightness contrast. In this photograph, the volcanic ash layer had a horizontal width of about $300 \mathrm{~km}$, a vertical thickness of about $3 \mathrm{~km}$ and an average mass concentration of about $0.5 \mathrm{mg} \mathrm{m}^{-3}$. The horizon and the ground are not visible due to the opacity of the ash layer. Fig. 6 f shows an example of a thin volcanic ash layer over Germany: in this case, the geometrical thickness of the volcanic ash layer was about $0.5 \mathrm{~km}$, and the maximum mass concentration was 0.05 (ranging from 0.03 to 0.11) $\mathrm{mg} \mathrm{m}^{-3}$ (Schumann et al., 2011).

The photographs presented here show clearly that the appearance and the visibility of volcanic ash to a pilot at the flight deck of an aircraft or an observer on the ground depends on a number of variables which are independent of the ash properties. Notably, the contrast between the ash cloud and the background (sky or ground) color, the position of the observer relative to the sun, the sun zenith angle, the geometrical thickness of the ash layer, and the viewing angle under which the observer sees the ash cloud are important factors. In addition, physiological aspects of human perception not further discussed here will play a role. The presence of water and ice clouds in the scene may hide volcanic ash even if the ash concentration is high enough to be seen under blue-sky conditions. Volcanic ash is not visible at night (except maybe for large concentrations during a full moon); yet, air traffic also takes place at night. (The engine blow-out of a Boeing 747-200 due to an encounter of ash from the Indonesian Galunggung volcano on 24 June 1982 happened at night (Casadevall, 1993)).

In summary, it is important to note that the appearance of airborne volcanic ash changes drastically with distance from the eruption site: close to the volcano $(<100-200 \mathrm{~km})$, a well-defined grayish "ash cloud" with sharp edges is visible. In contrast, several hundreds of kilometers away from the volcano, a wide-stretched and often inhomogeneous ash layer with blurry edges is visible. As the distance between the plume and the observer decreases, the edges of the plume appear less well defined, similar to a pilot's perception of cirrus clouds. Sometimes the emitted ash does not even form an extended layer, but rather fragments into numerous 

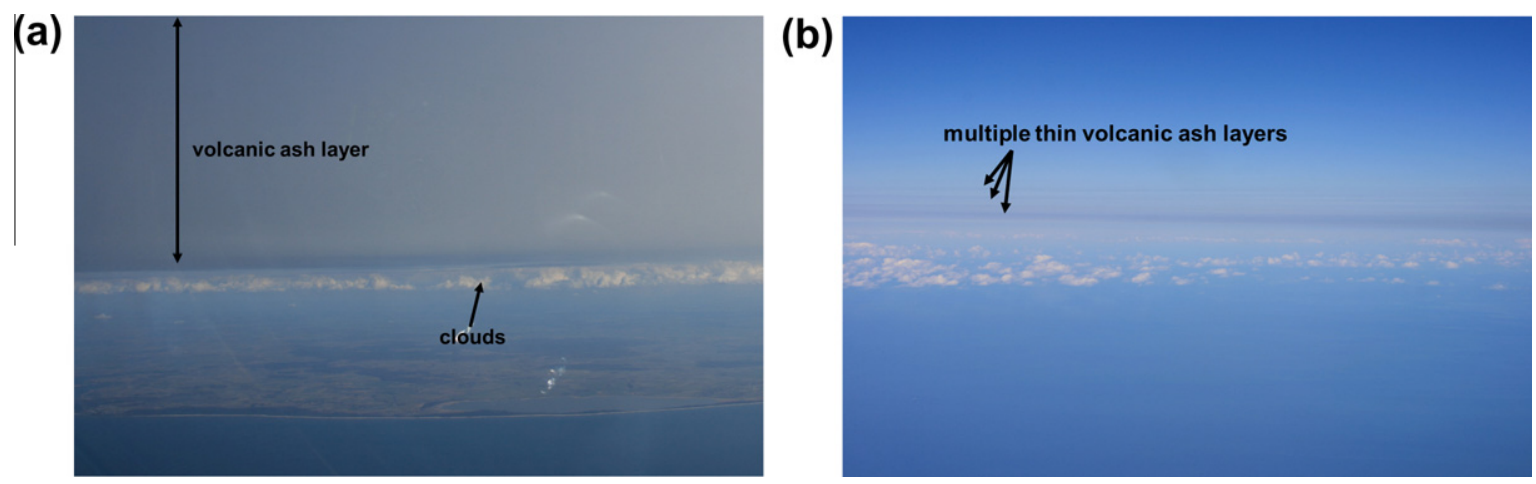

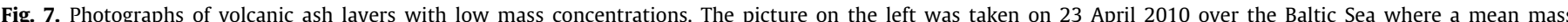

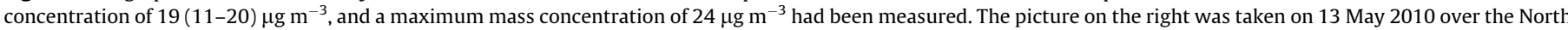

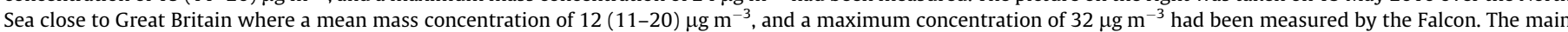
difference between both photographs is the geometrical thickness of the volcanic ash layers.

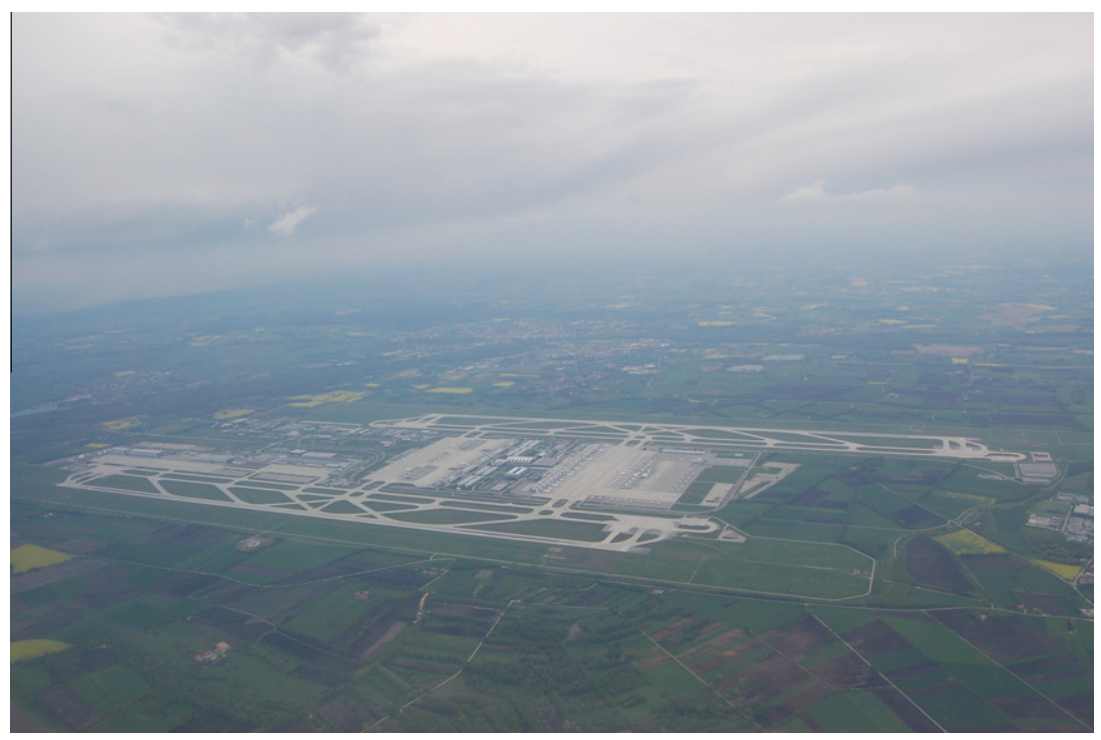

Fig. 8. Photograph showing the airport of Munich during airspace closure on 9 May 2010. On the picture, the volcanic ash layer cannot be identified although the ash mass concentration was similar (mean mass concentration: $17(11-27) \mu \mathrm{g} \mathrm{m}^{-3}$ ) to the mass concentrations measured over the Baltic Sea on 23 April 2010 (Fig. 7).
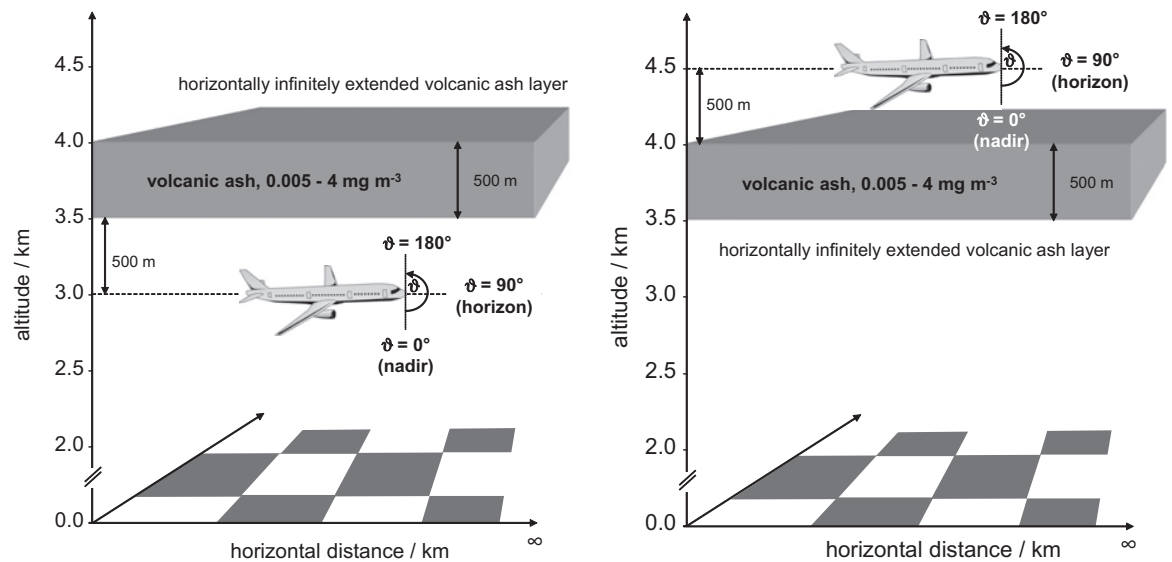

Fig. 9. Sketch of the set-up of our idealized simulations for the assessment on the question on the visibility of volcanic ash. For all our simulations, we used an idealized threedimensional, plane-parallel set-up. We choose an atmosphere without clouds and assumed an infinitely extended, homogeneous aerosol layer with a geometrical thickness of $500 \mathrm{~m}$ located between 3.5 and $4.0 \mathrm{~km}$. We performed simulations for three scenarios: the aircraft is below (left panel), in (not shown), and above (right panel) the volcanic ash layer. 
very thin filaments with a geometrical thickness on the order of $100 \mathrm{~m}$.

\subsection{Which concentrations of volcanic ash are visible under blue-sky conditions?}

The fact that the volcanic ash plume is visible as a grayishbrownish cloud close to the volcano and as grayish layer several hundreds of kilometers downstream of the volcano under cloudfree conditions raises the question of the minimum detectable mass concentration. We approach this question again from the inspection of photographs complemented with idealized radiative transfer simulations.

Fig. 7 shows two pictures of volcanic ash layers with mean mass concentrations lower than $0.02 \mathrm{mg} \mathrm{m}^{-3}$. The main difference between Fig. 7a and $b$ is the geometrical thickness of the volcanic ash layers: in Fig. 7a, the volcanic ash layer had a vertical thickness of more than $1.5 \mathrm{~km}$, whereas multiple thin layers, some of them thinner than $200 \mathrm{~m}$, are visible in Fig. 7b. We wish to emphasize that it is rather easy to identify the volcanic ash layers from the photographs because we know from our in situ and lidar measurements that volcanic ash layers were present. However, during the flight on 23 April over the Baltic Sea (Fig. 7a) the presence of a volcanic ash layer was much less clear.

Fig. 8 shows an aerial view of the airport of Munich during airspace closure on 9 May 2010. Here, the volcanic ash layer is not visible on the photograph although ash with a mean mass concentration of $0.02(0.01-0.03) \mathrm{mg} \mathrm{m}^{-3}$ was present, which is comparable to the mass concentrations measured over the Baltic Sea on 23 April 2010 (Fig. 7a). The clouds decrease the contrast between the volcanic ash and the background substantially. Fig. 8 demonstrates that the presence of clouds makes it very difficult, if not impossible, to identify volcanic ash by sight. Therefore, an observer who is already aware of the presence of volcanic ash would probably be able to see layers with concentrations of about $0.02 \mathrm{mg} \mathrm{m}^{-3}$ under optimal viewing conditions, however, an uninformed observer would probably fail to note an ash layer.

To further assess the visibility threshold of volcanic ash and to determine the minimum mass concentration in a layer that can be identified by a pilot, we performed a series of radiative transfer simulations with MYSTIC (see Section 2.2). For all simulations, we used a highly idealized set-up and choose an atmosphere without clouds. Fig. 9 sketches the set-up in our three-dimensional, planeparallel model: we assumed a homogeneous aerosol layer located at between 3.5 and $4.0 \mathrm{~km}$ altitude. Aerosols are located only in the distinct, 500-m thick and infinitely extended layer bordered by an aerosol-free atmosphere above and below. To add some artificial contrast to the simulation, the surface albedo in the model runs was set to a chess board pattern with 1 by $1 \mathrm{~km}$ squares with albedo 0.2 and 0 , respectively. This set-up resembles the observation of volcanic ash several hundred kilometers downwind from the volcano and for meteorological conditions dominated by the presence of a high-pressure system, as was observed in April/ May 2010.

The first set of model runs addressed the question at which minimum concentration can the presence of volcanic ash be identified by an observer located $500 \mathrm{~m}$ either above or below the aerosol layer. For that purpose we show a $1^{\circ}$ wedge in the horizontal direction as a function of the ash mass concentration. The total vertical opening angle $\vartheta$ (see Fig. 9) is $\pm 60^{\circ}$ relative to the horizon (inclination angle, at the horizon $\vartheta=90^{\circ}$ ) in this simulation, the solar zenith angle is $75^{\circ}$, that means, the sun is $15^{\circ}$ above the horizon. In each model run we increased the aerosol concentration linearly from 0 to $4 \mathrm{mg} \mathrm{m}^{-3}$ in 240 steps. The resulting sections were combined into a single image shown in Figs. 11 and 12. Note that these images are different from the panorama views in the next section because here the relative angle between the viewing direction and the sun

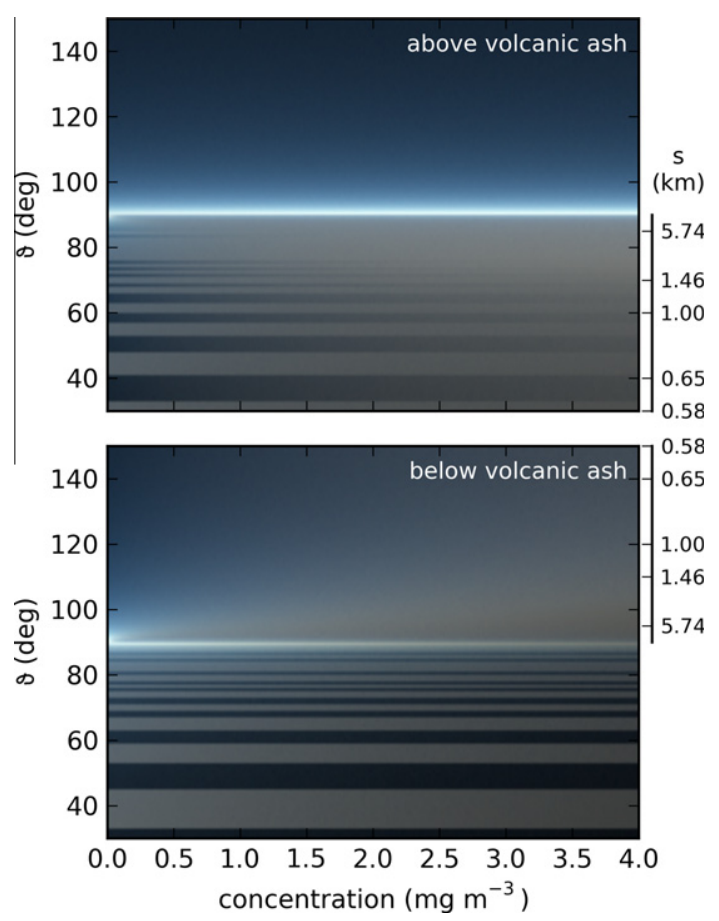

Fig. 11. Assessment of the minimum visible ash concentration. On the $x$-axis the concentration of volcanic ash aerosol is increased linearly in 240 steps from 0 to $4 \mathrm{mg} \mathrm{m}^{-3}$. Each vertical pixel is computed assuming a $1^{\circ}$ opening angle $\varphi$ with viewing direction away from the sun. The left scale gives the zenith angle $\vartheta$, the right scale indicates the path length along the line-of-sight, $s=d / \cos \vartheta$, inside the volcanic ash layer for the corresponding viewing angle assuming a geometrical thickness of $d=500 \mathrm{~m}$. The solar zenith angle is $75^{\circ}$, that means, the sun is $15^{\circ}$ above the horizon.

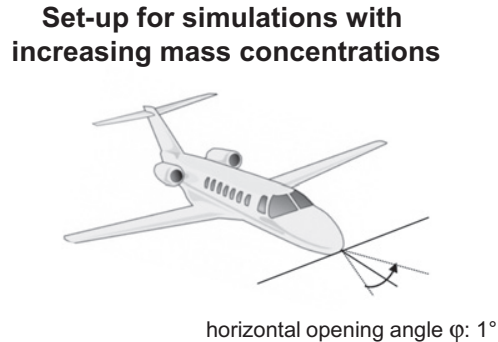

\section{Set-up for panorama simulations}

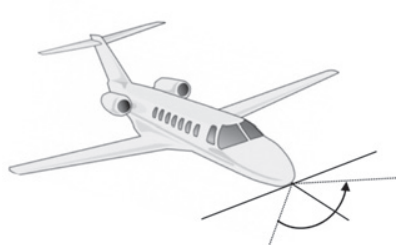

horizontal opening angle $\varphi: 120^{\circ}$

Fig. 10. Sketch of the opening angle $\varphi$ used for the simulations with increasing mass concentrations (Section 4.2) and for the set-up of the panorama simulations (Section 4.3). 


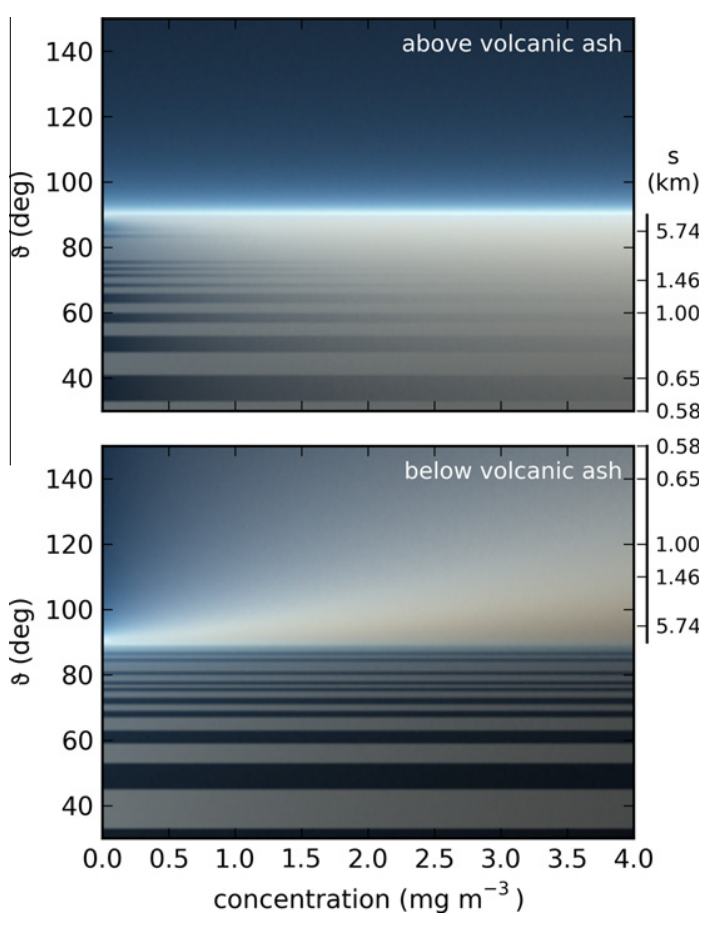

Fig. 12. Same as Fig. 11 but with an azimuthal viewing direction of $60^{\circ}$ relative to the sun.

does not change along the $x$-axis. The viewing direction was exactly away from the sun (i.e., the sun was in the back of the observer). In Fig. 11 the horizontal viewing direction was $60^{\circ}$ relative to the sun. We also did calculations facing the sun, however the images are so strongly dominated by the forward scattered light that no clear features are visible (see the next section for an example). The left scale on each image gives the inclination angle $\vartheta$ such that $0^{\circ}$ corresponds to nadir, $90^{\circ}$ to the horizon, and $180^{\circ}$ to zenith. The scale to the right of each plot indicates the path length inside the volcanic ash layer for the corresponding inclination angle according to $s=d$ / $\cos \vartheta$ for a layer thickness of $d=500 \mathrm{~m}$. From those images it is apparent that close to the horizon even fairly small aerosol concentrations are visible, however at a few degrees off the horizon, the layers with low concentrations are no longer apparent. For the view from below the aerosol layer, away from the sun and $\sim 20^{\circ}$ off the horizon the aerosol layer starts to be visible at concentrations of about $0.75 \mathrm{mg} \mathrm{m}^{-3}$. For the view from above, the layer is vaguely identifiable at about $0.25-0.5 \mathrm{mg} \mathrm{m}^{-3}$. In the situation depicted in Fig. 12 with a horizontal viewing angle of $60^{\circ}$ relative to the sun, the aerosol layers are visible at concentrations down to about $0.4 \mathrm{mg} \mathrm{m}^{-3}$ irrespective of whether the observer is located below or above the layer. For viewing angles further away from the horizon (i.e., shorter line-of-sight inside the ash layer) the detectable concentrations thresholds become considerably larger. These numbers indicate the lower limit of ash concentration for ash visibility under idealized conditions without clouds during the day for this specific layer geometry. Geometrically thicker layers will lead to longer line-of-sight paths inside the ash layer lowering the minimum detectable concentration.

In a working paper prepared by the science sub-group of the International Volcanic Ash Task Force (IVATF, 2011), estimates for the visibility of volcanic ash clouds under different conditions were presented based on observational and theoretical considerations. The authors used a completely different approach to estimate what they call "visible ash" based on the discussion of visibility of cirrus clouds against the background of blue sky by Sassen et al. (1989). For an effective radius of $3 \mu \mathrm{m}$ and a layer thickness of $1 \mathrm{~km}$ they estimate that an ash cloud with concentration of $0.1 \mathrm{mg} \mathrm{m}^{-3}$ should be visible under clear-sky conditions. The thickness of $1 \mathrm{~km}$ corresponds to a viewing angle of $60^{\circ}$ (observer above the layer) or $120^{\circ}$ (observer below the layer) in our simulations. Under such conditions our simulations lead to substantially higher estimates for the detectable concentration threshold. In direct comparison to clean conditions in the same field of view the ash is already visible at much lower concentrations. Fig. 13 illustrates this aspect. The simulations shown here are computed with the same setup as in Fig. 12, but here we only show 12 different concentrations (right half of all panels) in direct comparison to clean conditions without aerosols (left half of all

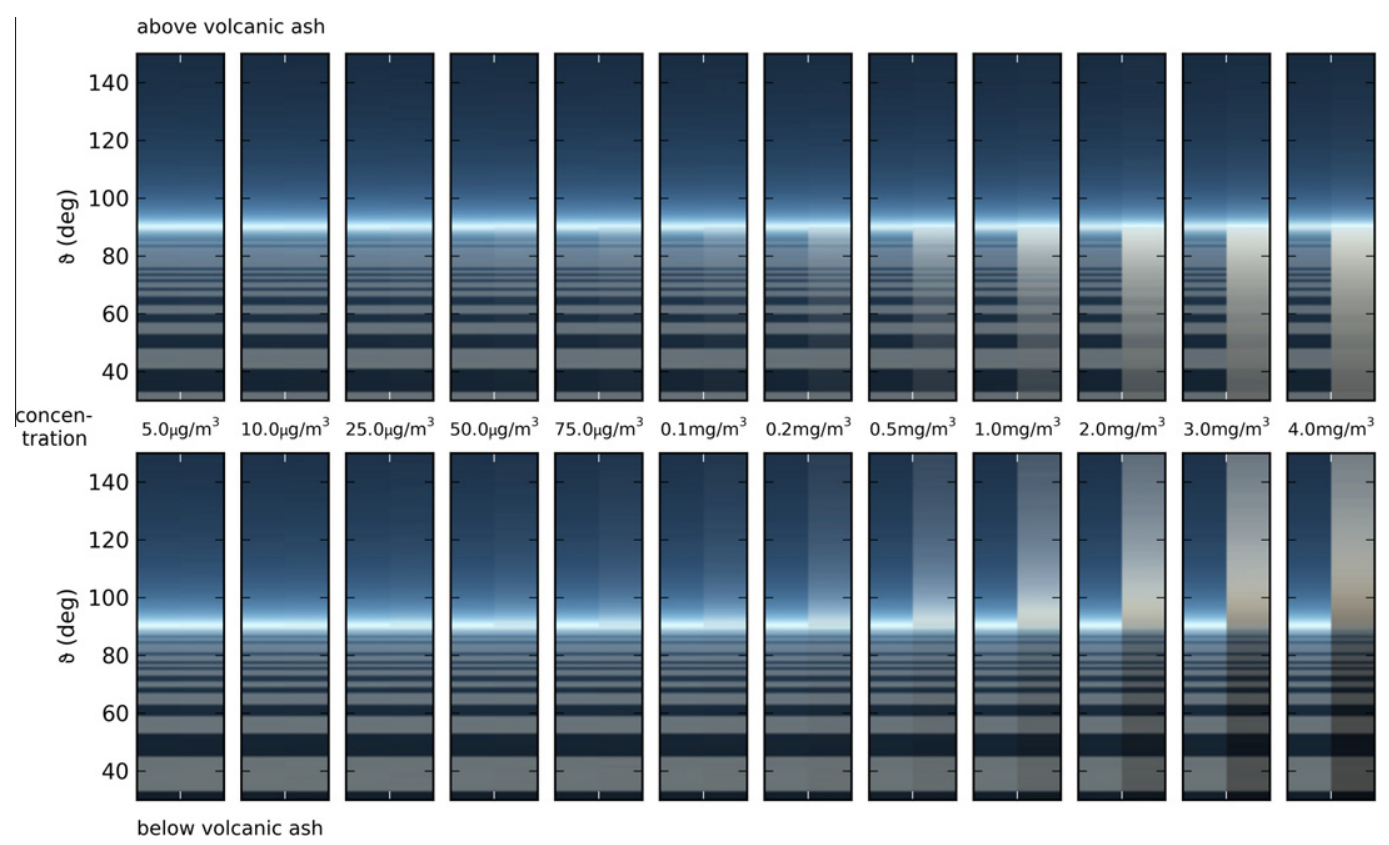

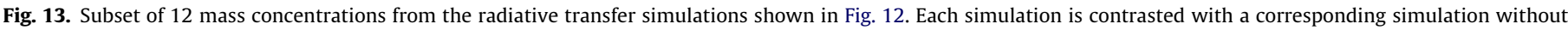
aerosol in the left half of each panel. 
panels). With the direct comparison to clean conditions, the aerosol layer is visible already at concentrations between 0.25 and $0.5 \mathrm{mg} \mathrm{m}^{-3}$ which agrees with the results of the aforementioned working paper, and also with the analysis of our own photographs (Figs. 6 and 7).

\subsection{Can a pilot distinguish volcanic ash layers from other aerosol layers, such as mineral dust?}

In Section 3.2, we showed that mineral dust and volcanic ash have rather similar properties, but they can be distinguished via their microphysical and optical properties. To address whether it is possible to distinguish volcanic ash and mineral dust layers by sight we simulated the view as it would be seen from an airplane cockpit located $500 \mathrm{~m}$ below, inside, and above an aerosol layer now assuming a horizontal opening angle of $120^{\circ}$ (see Figs. 9 and 10 , right panel) and a vertical opening angle of $\pm 30^{\circ}$. As before, the sun is located at a solar zenith angle of $75^{\circ}$. The resolution of those simulations is 2 pixels per degree at the horizon in horizontal and vertical direction. The aerosol density is set to the maximum density currently permitted for air traffic in a volcanic ash plume of $2 \mathrm{mg} \mathrm{m}^{-3}$. In this setup the volcanic ash layer has a total (vertical) AOD of 0.5. Mineral dust has a smaller extinction coefficient resulting in a somewhat lower (vertical) AOD of 0.4. For non-vertical viewing angles, the AOD increases and scales with $1 / \cos \vartheta$. The images in Figs. 14 and 15 show the visual difference between a layer of volcanic ash (left panels) and mineral dust (right panels) from a pilot's perspective. The observer's view is directed away from the sun in Fig. 14 and towards the sun in Fig. 15. The position of the sun is marked with a red cross in the images in Fig. 15 (at the resolution of $0.5^{\circ}$ used for these calculations the direct sun would cover about one pixel). To increase the contrast in the images in Fig. 15a and b, a brightness cut-off was applied above which pixels appear white corresponding to the saturation of the eye. For both images the same cut-off has been used to ensure the comparability of the images, that means, identical "exposure time" and "aperture" of the camera. Additionally, in all images in Figs. 14 and 15 the radiance in each pixel is scaled with a gamma correction of $\gamma=2$ via $L^{1 / \gamma}$ to increase the contrast mimicking the sensitivity of a human eye.

While some small differences in color and angular dependence of light scattering are visible in the direct comparison, no striking feature is apparent that would allow for distinguishing volcanic ash from mineral dust visually. Mineral dust has a somewhat redder color than volcanic ash and is slightly less absorbing. Furthermore, mineral dust shows only a mono-modal volume size distribution, whereas volcanic ash is (in the present case) characterized by a bi-modal size distribution. However, for an observer flying an aircraft and relying on sight alone without a comparison image, the differences are too subtle to distinguish between the two aerosol types. Furthermore, an observer onboard flying inside a thin aerosol layer (situation shown in the middle panels in Figs. 14 and 15) might still have the visual impression that the aircraft is flying above the layer.

In this study, we only compared volcanic ash and mineral dust, however, other aerosol types such as biomass burning aerosol are observed in the atmosphere. The photograph in Fig. 16 shows that biomass burning aerosol also may have a grayish appearance. Therefore, we want to emphasize that the observation of a grayish-brownish layer in the atmosphere does not unambiguously indicate the presence of volcanic ash.

In regions with high aerosol loading in the atmosphere from natural or anthropogenic influences, such as seen in large parts of Asia, the visual detection of an additional volcanic ash layer against the background of other aerosol will be substantially more difficult.
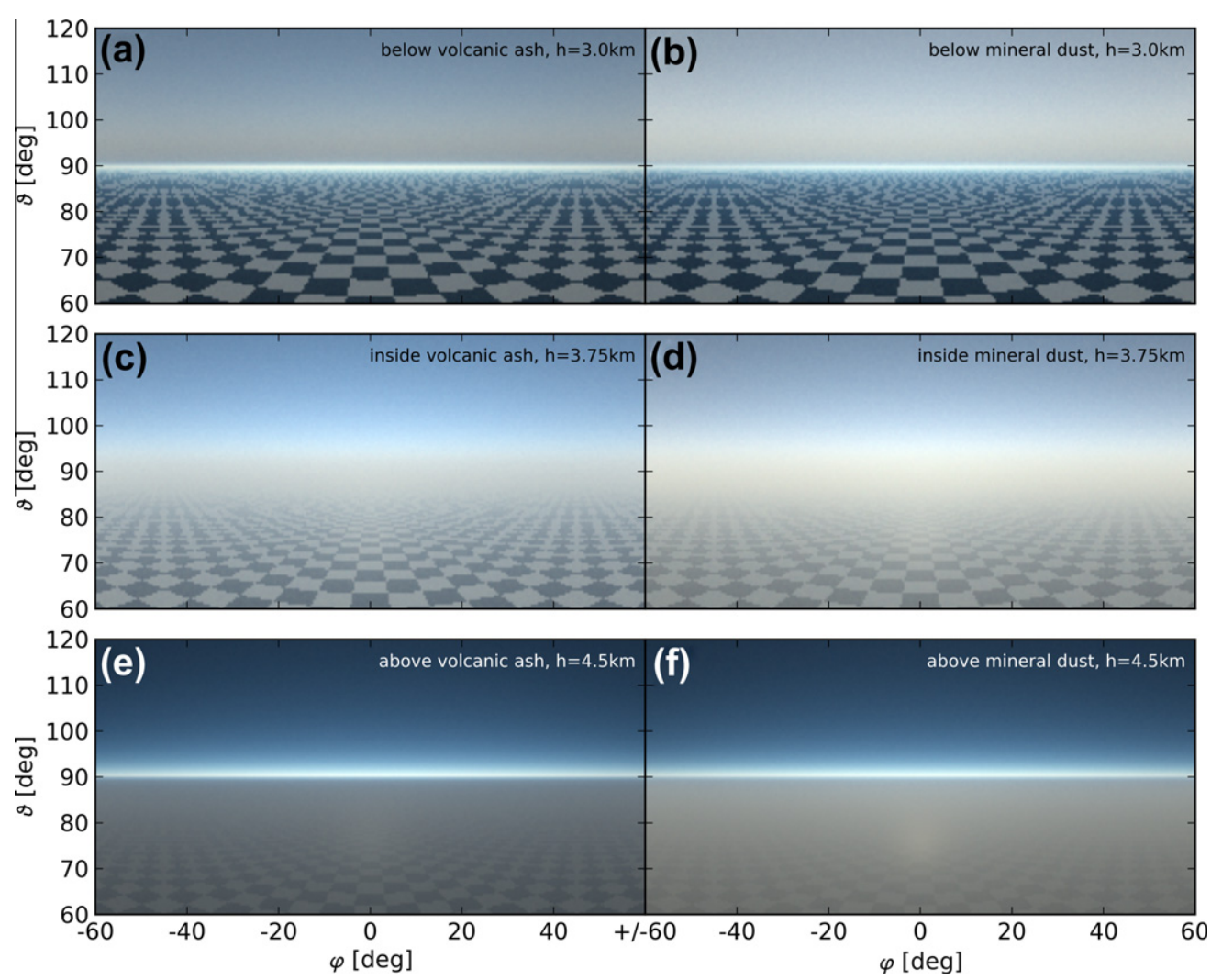

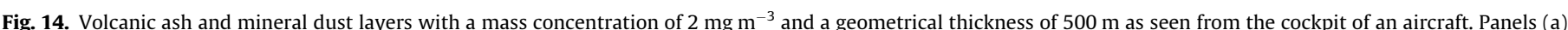

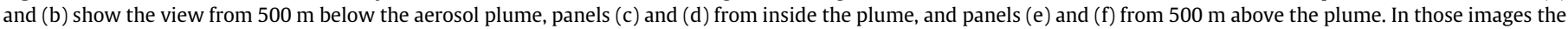
observer's view is away from the sun. 

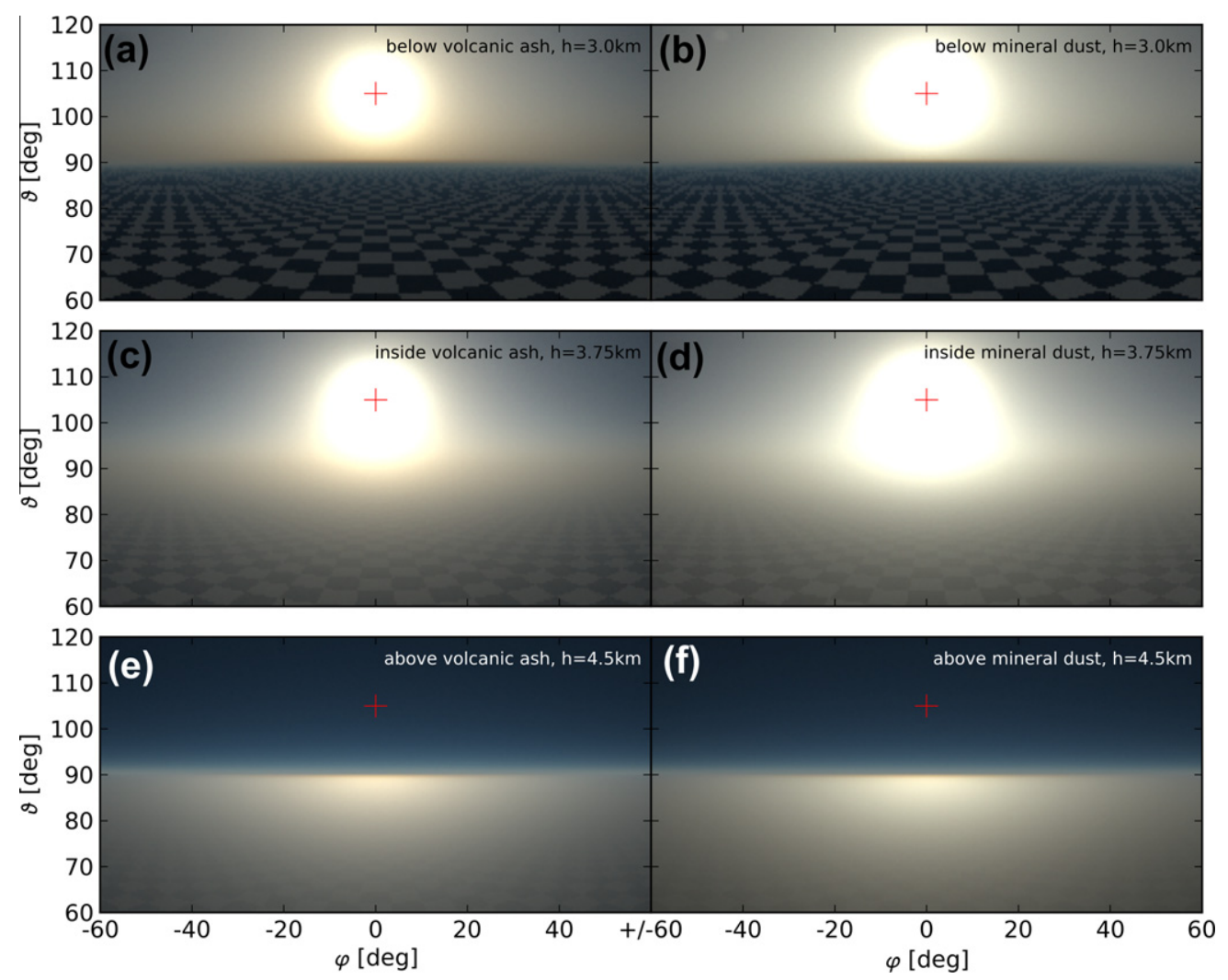

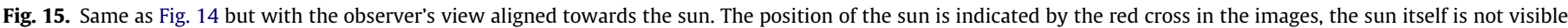
because photons reaching the observer directly without interaction are omitted from the model calculation.

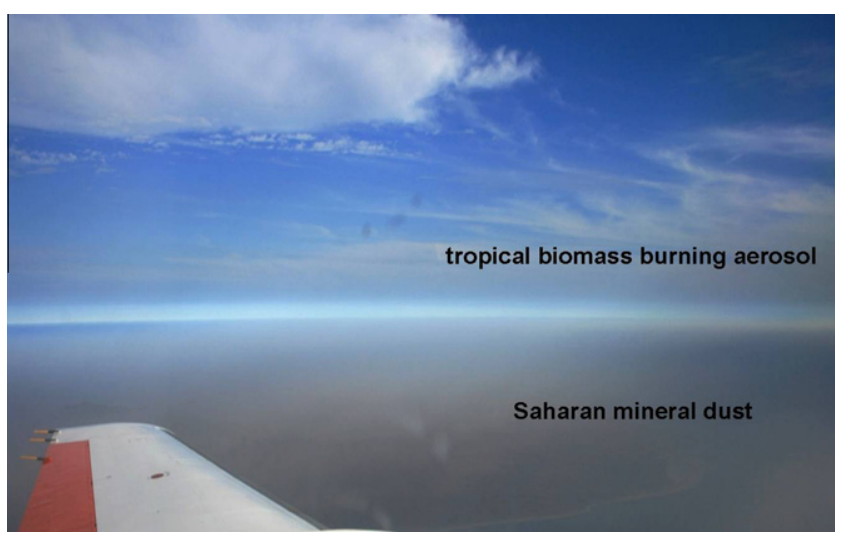

Fig. 16. Photograph of a biomass burning layer covering the altitude range between 2 and $6 \mathrm{~km}$, and a mineral dust layer extending from 0.3 to $1.3 \mathrm{~km}$ altitude. The aerosol layers were observed in the Cape Verde region on 19 January 2008. The Falcon was below the biomass burning layer and above the mineral dust layer at the time this picture was taken. The corresponding lidar image is shown in Fig. 7 in Weinzierl et al. (2011).

\section{Summary and conclusions}

Several incidents in the past have demonstrated that volcanic ash can have severe consequences on aviation. With the safety criterion "no flight in visible ash" in mind, we investigated whether a pilot has the ability to visually detect the presence of potentially dangerous volcanic ash (i.e., with mass concentration larger than $2 \mathrm{mg} \mathrm{m}^{-3}$ ) and safely avoid affected regions. The visual detectability of airborne volcanic ash at various distances from the volcano was discussed based on observations and simulations with a radiative transfer model.
Our results show that the assessment of the visual detectability of airborne volcanic ash or other aerosols is very complex because the detectability depends on many parameters, such as the size/ distance ratio, the brightness and the color contrast between the airborne volcanic ash and the background, illumination, particle size distribution and mass concentration, wavelength-dependent light scattering and absorption by the ash, and human perception. The results emphasize that it is not sufficient to solely investigate the optical depth of the airborne volcanic ash to characterize visibility and detectability.

The appearance of airborne volcanic ash changes drastically during transport due to dilution with surrounding air and sedimentation-loss of the larger particles: close to the volcano, a well-defined grayish "ash cloud" with sharp edges is visible, while several hundreds of kilometers downwind from the volcano, only a grayish-brownish, widely-stretched and often inhomogeneous ash layer with rather blurry edges is visible.

We contrasted the microphysical and optical properties of Eyjafjalla volcanic ash and Saharan mineral dust. The volcanic ash layers investigated during the Eyjafjalla research flights exhibited a bi-modal volume size distribution consisting of a mixture of ash particles and sulfuric acid droplets/particles, while mineral dust layers showed only a very distinct coarse mode. The volcanic ash was slightly more absorbing than mineral dust, and the spectral behavior of the refractive index was slightly different. However, according to our simulations these differences are not detectable by the human eye. In addition, biomass burning or anthropogenic pollution aerosol also has a grayish appearance. Therefore, the presence of a grayish-brown layer in the atmosphere does not unambiguously indicate the presence of volcanic ash. An uninformed observer not being aware of the potential presence of airborne volcanic ash is unlikely to recognize an aged volcanic ash layer in his field of view without further information. 
The minimum detectable mass concentration scales with the vertical thickness of the aerosol layer and the viewing angle through the layer. For the setup used in our simulation (ash layer with a vertical thickness of $500 \mathrm{~m}$ ), we found that the aerosol layer is already visible at concentrations between 0.25 and $0.5 \mathrm{mg} \mathrm{m}^{-3}$, depending on the viewing angle $\vartheta$ and if the observer has a direct comparison to clear-sky conditions. However, it is not possible to visually determine whether a volcanic ash layer is potentially dangerous (mass concentration smaller or larger than $2 \mathrm{mg} \mathrm{m}^{-3}$ ). Regardless of concentration, volcanic ash is not visible at night. Furthermore, the visibility of an aged volcanic ash layer will also be strongly hampered if it becomes embedded into the planetary boundary layer with high concentrations of particulate pollutants, which can easily be the case in industrialized regions.

The implications of our study for aircraft operation are the following: under clear-sky conditions, volcanic ash is visible at concentrations far below the limit for safe flying, but it is impossible to determine visually when the threshold of $2 \mathrm{mg} \mathrm{m}^{-3}$ is exceeded. Volcanic ash cannot be distinguished visually from other aerosol layers, such as mineral dust. To prevent a scenario similar to the "Eyjafjalla ash crisis" in the future, we need reliable tools to predict and identify regions free of dangerous ash loads. These tools have to be certified and implemented in the decision processes.

We want to emphasize that the idealized simulations shown in this study make no claim to be complete. The setup of our simulations was deliberately kept simple and was confined to a few cases with selected viewing geometries. We investigated the best-case scenario with no additional clouds present. We expect that the presence of clouds would make a visual detection of volcanic ash substantially more difficult because clouds either block the direct sight to the ash layer entirely or at least reduce the contrast to the background.

\section{Acknowledgements}

This work was funded by the Helmholtz Association under Grant number VH-NG-606 (Helmholtz-Hochschul-Nachwuchsforschergruppe AerCARE), and by the Deutsche Forschungsgemeinschaft (DFG) under Grant number FOR 539 (Forschergruppe SAMUM). The volcanic ash research flights with the DLR Falcon were funded by the Bundesministerium für Verkehr, Bau und Stadtentwicklung (BMVBS, Federal Ministry of Transport, Building and Urban Development). We thank the Falcon flight crew, DLR flight operations, and all participants of the SAMUM and the Eyjafjalla volcanic ash field campaigns for the excellent collaboration. We would like to thank Martin Wirth (DLR) for providing three-dimensional plots of the lidar data.

\section{References}

Anderson, G.P., Clough, S.A., Kneizys, F.X., Chetwynd, J.H., Shettle, E.P., 1986. AFGL Atmospheric Constituent Profiles (0-120 km), Tech. Rep. AFGL-TR-86-0110.

Ansmann, A., Petzold, A., Kandler, K., Tegen, I., Wendisch, M., Müller, D., Weinzierl, B., Müller, T., Heintzenberg, J., 2011a. Saharan mineral dust experiments SAMUM-1 and SAMUM-2: what have we learned? Tellus 63B, 403-429. http:// dx.doi.org/10.1111/j.1600-0889.2011.00555.x.

Ansmann, A. Tesche, M., Gross, S., Freudenthaler, V., Seifert, P., Hiebsch, A., Schmidt J., Wandinger, U., Mattis, I., Müller, D., Wiegner, M., 2010. The 16 April 2010 major volcanic ash plume over central Europe: EARLINET lidar and AERONET photometer observations at Leipzig and Munich. Germany. Geophys. Res. Lett. 37, L13810. http://dx.doi.org/10.1029/2010gl043809.

Ansmann, A., Tesche, M., Seifert, P., Gross, S., Freudenthaler, V., Apituley, A., Wilson, K.M., Serikov, I., Linne, H., Heinold, B., Hiebsch, A., Schnell, F., Schmidt, J., Mattis, I. Wandinger, U., Wiegner, M., 2011b. Ash and fine-mode particle mass profiles from EARLINET-AERONET observations over central Europe after the eruptions of the Eyjafjallajokull volcano in 2010. J. Geophys. Res. 116, D00u02. http:// dx.doi.org/10.1029/2010jd015567.
Buras, R., Mayer, B., 2011. Efficient unbiased variance reduction techniques for Monte Carlo simulations of radiative transfer in cloudy atmospheres: the solution. J. Quant. Spectrosc. Radiat. Trans. 112, 434-447. http://dx.doi.org/ 10.1016/j.jqsrt.2010.10.005.

Casadevall, T.J., 1993. Volcanic Hazards and Aviation Safety: Lessons of the Past Decade. Flight Safety Foundation - Flight Safety Digest, pp. 1-9.

Casadevall, T.J., 1994. The 1989-1990 eruption of Redoubt Volcano, Alaska: impacts on aircraft operations. J. Volcanol. Geothermal Res. 62, 301-316. http:// dx.doi.org/10.1016/0377-0273(94)90038-8.

Clarke, A.D., 1991. A thermo-optic technique for in situ analysis of size-resolved aerosol physicochemistry. Atmos. Environ. 25A, 635-644. http://dx.doi.org/ 10.1016/0960-1686(91)90061-B.

Colarco, P.R., Toon, O.B., Reid, J.S., Livingston, J.M., Russell, G., Redemann, J., Schmid, B., Maring, H., Savoie, D., Welton, E.J., Campbell, J.R., Holben, B., Levy, R., 2003. Saharan dust transport to the Caribbean during PRIDE: 2. Transport, vertical profiles, and deposition in simulations of in situ and remote sensing observations. J. Geophys. Res. 108, 8590. http://dx.doi.org/10.1029/ 2002JD002659.

Dingwell, D.B., 1996. Volcanic dilemma-flow or blow? Science 273, 1054-1055 http://dx.doi.org/10.1126/science.273.5278.1054.

Emde, C., Buras, R., Mayer, B., Blumthaler, M., 2010. The impact of aerosols on polarized sky radiance. model development, validation, and applications. Atmos. Chem. Phys. 10, 383-396. http://dx.doi.org/10.5194/acp-10-383-2010.

Emde, C., Mayer, B., 2007. Simulation of solar radiation during a total eclipse: a challenge for radiative transfer. Atmos. Chem. Phys. 7, 2259-2270. http:// dx.doi.org/10.5194/acp-7-2259-2007.

Esselborn, M., Wirth, M., Fix, A., Weinzierl, B., Rasp, K., Tesche, M., Petzold, A., 2009. Spatial distribution and optical properties of Saharan dust observed by airborne High Spectral Resolution Lidar during SAMUM 2006. Tellus 61B, 131-143. http://dx.doi.org/10.1111/j.1600-0889.2008.00394.x.

Fiebig, M., 2001. Das troposphärische Aerosol in mittleren Breiten - Mikrophysik, Optik und Klimaantrieb am Beispiel der Feldstudie LACE 98, Physik. LudwigMaximilians-Universität, München, p. 244.

Gasteiger, J., Gross, S., Freudenthaler, V., Wiegner, M., 2011. Volcanic ash from Iceland over Munich: mass concentration retrieved from ground-based remote sensing measurements. Atmos. Chem. Phys. 11, 2209-2223. http://dx.doi.org/ 10.5194/acp-11-2209-2011.

Guffanti, M., Casadevall, T.J., Budding, K., 2010. 1953-2009: Encounters of Aircraft with Volcanic Ash Clouds, A Compilation of Known Incidents. U.S. Geological Survey Data Series 545, 12 p., Plus 4 Appendixes Including the Compilation Database. <http://pubs.usgs.gov/ds/545/>.

Heinold, B., Tegen, I., Esselborn, M., Kandler, K., Knippertz, P., Müller, D., Schladitz, A., Tesche, M., Weinzierl, B., Ansmann, A., Althausen, D., Laurent, B., Massling, A., Müller, T., Petzold, A., Schepanski, K., Wiedensohler, A., 2009. Regional Saharan dust modelling during the SAMUM 2006 campaign. Tellus 61B, 307-324. http:// dx.doi.org/10.1111/j.1600-0889.2008.00387.x.

Heinold, B., Tegen, I., Wolke, R., Ansmann, A., Mattis, I., Minikin, A., Schumann, U., Weinzierl, B., 2011. Simulations of the 2010 Eyjafjallajökull volcanic ash dispersal over Europe using COSMO-MUSCAT. Atmos. Environ.. http:// dx.doi.org/10.1016/j.atmosenv.2011.05.021.

Heintzenberg, J.O.S.T., 2009. The SAMUM-1 experiment over Southern Morocco: overview and introduction. Tellus 61B, 2-11. http://dx.doi.org/10.1111/j.16000889.2008.00403.x.

Hinds, W.C., 1999. Aerosol Technology: Properties, Behaviour and Measurement of Airborne Particles. John Wiley \& Sons, Inc., New York.

Horvath, H., 1971. On the applicability of the Koschmieder visibility formula. Atmos. Environ. 5, 177-184. http://dx.doi.org/10.1016/0004-6981(71)90081-3.

Huang, J.F., Zhang, C.D., Prospero, J.M., 2010. African dust outbreaks: a satellite perspective of temporal and spatial variability over the tropical Atlantic Ocean. J. Geophys. Res. 115, D05202. http://dx.doi.org/10.1029/2009jd012516.

ICAO, 2001. Manual on Volcanic Ash, Radioactive Material and Toxic Chemical Clouds (First Edition), Doc 9691-AN/954 pp. variously paged. <http:// www.icao.int/safety/meteorology/iavwopsg/Meeting\%2020Documents/ IAVWOPSG-2011/Report/Appendix\%2020E.pdf> (accessed 19.03.12).

ICAO, 2007. Manual on Volcanic Ash, Radioactive Material and Toxic Chemical Clouds (Second Edition), Doc 9691-AN/954, pp. variously paged. <http:// www.paris.icao.int/news/pdf/9691.pdf> (accessed 19.03.12).

IVATF, 2011. International Volcanic Ash Task Force TF-SCI03 Progress Report (Part I) Understanding "visible ash". <http://www2.icao.int/en/anb/met/ivatf/ Documents/IVATF.2.WP.008.2.en.pdf $>$ (accessed 19.03.12).

Kandler, K., Lieke, K., Benker, N., Emmel, C., Küpper, M., Müller-Ebert, D., Ebert, M., Scheuvens, D., Schladitz, A., Schütz, L., Weinbruch, S., 2011. Electron microscopy of particles collected at Praia, Cape Verde, during the Saharan Mineral dust experiment: particle chemistry, shape, mixing state and complex refractive index. Tellus 63B, 475-496. http://dx.doi.org/10.1111/j.16000889.2011.00550.x.

Kandler, K., Schütz, L., Deutscher, C., Ebert, M., Hofmann, H., Jäckel, S., Jaenicke, R., Knippertz, P., Lieke, K., Massling, A., Petzold, A., Schladitz, A., Weinzierl, B. Wiedensohler, A., Zorn, S., Weinbruch, S., 2009. Size distribution, mass concentration, chemical and mineralogical composition and derived optical parameters of the boundary layer aerosol at Tinfou, Morocco, during SAMUM 2006. Tellus 61B, 32-50. http://dx.doi.org/10.1111/j.1600-0889.2008.00385.x.

Knippertz, P., Todd, M.C., 2012. Mineral dust aerosols over the Sahara: meteorological controls on emission and transport and implications for modeling. Rev. Geophys. 50, RG1007. http://dx.doi.org/10.1029/2011rg000362. 
Koschmieder, H., 1925. Theorie der horizontalen Sichtweite. Beiträge z. Physik der freien Atmosphäre 12, 33-55.

Kueppers, U., Cimarelli, C., Hess, K.U., Dingwell, D.B., Rickerby, D.S., Madden, P., 2010. Thermal stability of volcanic ash versus turbine ingestion test sands: an experimental investigation. Atlantic Conference on Eyjafjallajökull and Aviation, Keflavik, Iceland.

Lavallée, Y., Varley, N., Alatorre-Ibargüengoitia, M., Hess, K.U., Kueppers, U., Mueller, S., Richard, D., Scheu, B., Spieler, O., Dingwell, D., 2012. Magmatic architecture of dome-building eruptions at Volcán de Colima, Mexico. Bull. Volcanol. 74, 249260. http://dx.doi.org/10.1007/s00445-011-0518-4

Lieke, K., Kandler, K., Scheuvens, D., Emmel, C., von Glahn, C., Petzold, A., Weinzierl, B., Veira, A., Ebert, M., Weinbruch, S., Schütz, L., 2011. Particle chemical properties in the vertical column based on aircraft observations in the vicinity of Cape Verde Islands. Tellus 63B, 497-511. http://dx.doi.org/10.1111/j.16000889.2011.00553.x.

Mahowald, N.M., Baker, A.R., Bergametti, G., Brooks, N., Duce, R.A., Jickells, T.D. Kubilay, N., Prospero, J.M., Tegen, I., 2005. Atmospheric global dust cycle and iron inputs to the ocean. Global Biogeochem. Cycles 19, 1-15. http://dx.doi.org/ 10.1029/2004GB002402.

Mattis, I., Müller, D., Ansmann, A., Wandinger, U., Preißler, J., Seifert, P., Tesche, M., 2008. Ten years of multiwavelength Raman lidar observations of freetropospheric aerosol layers over central Europe: geometrical properties and annual cycle. J. Geophys. Res. 113, D20202. http://dx.doi.org/10.1029/ 2007JD009636.

Mayer, B., 2009. Radiative Transfer in the Cloudy Atmosphere. E.D.P. Sciences, Cedex

Mayer, B., Kylling, A., 2005. Technical note: the libRadtran software package for radiative transfer calculations - description and examples of use. Atmos. Chem. Phys. 5, 1855-1877. http://dx.doi.org/10.5194/acp-5-1855-2005.

Mechnich, P., Braue, W., Schulz, U., 2011. High-temperature corrosion of EB-PVD yttria partially stabilized zirconia thermal barrier coatings with an artificial volcanic ash overlay. J. Am. Ceram. Soc. 94, 925-931. http://dx.doi.org/10.1111/ j.1551-2916.2010.04166.x

Mishchenko, M.I., Travis, L.D., 1998. Capabilities and limitations of a current FORTRAN implementation of the T-matrix method for randomly oriented, rotationally symmetric scatterers. J. Quant. Spectrosc. Radiat. Transf. 60, 309324. http://dx.doi.org/10.1016/s0022-4073(98)00008-9.

Moulin, C., Chiapello, I., 2006. Impact of human-induced desertification on the intensification of Sahel dust emission and export over the last decades. Geophys. Res. Lett. 33, 1-5. http://dx.doi.org/10.1029/2006GL025923.

Müller, D., Mattis, I., Wandinger, U., Ansmann, A., Althausen, D., Dubovik, O., Eckhardt, S., Stohl, A., 2003. Saharan dust over a central European EARLINETAERONET site: combined observations with Raman lidar and Sun photometer. J. Geophys. Res. 108, 4345. http://dx.doi.org/10.1029/2002JD002918.

Newhall, C.G., Self, S., 1982. The volcanic explosivity index (VEI) - an estimate of the explosive magnitude for historical volcanism. J. Geophys. Res. 87, 1231-1238. http://dx.doi.org/10.1029/JC087iC02p01231.

Parker, D.E., Wilson, H., Jones, P.D., Christy, J.R., Folland, C.K., 1996. The impact of Mount Pinatubo on world-wide temperatures. Int. J. Climatol. 16, 487-497. http://dx.doi.org/10.1002/(SICI)1097-0088(199605)16:5<487::AIDJOC39>3.0.CO;2-J.

Petersen, G.N., Bjornsson, H., Arason, P., 2012. The impact of the atmosphere on the Eyjafjallajokull 2010 eruption plume. J. Geophys. Res., 117. http://dx.doi.org/ 10.1029/2011jd016762.

Petzold, A., Rasp, K., Weinzierl, B., Esselborn, M., Hamburger, T., Dörnbrack, A. Kandler, K., Schütz, L., Knippertz, P., Fiebig, M., Virkkula, A., 2009. Saharan dust absorption and refractive index from aircraft-based observations during SAMUM 2006. Tellus 61B, 118-130. http://dx.doi.org/10.1111/j.16000889.2008.00383.x.

Petzold, A., Veira, A., Mund, S., Esselborn, M., Kiemle, C., Weinzierl, B., Hamburger, T., Ehret, G., Lieke, K. Kandler, K, 2011. Mixing of mineral dust with urban pollution aerosol over Dakar (Senegal): impact on dust physico-chemical and radiative properties. Tellus 63B, 619-634. http://dx.doi.org/10.1111/j.16000889.2011.00547x.

Prospero, J.M., Ginoux, P., Torres, O., Nicholson, S.E., Gill, T.E., 2002. Environmenta characterization of global sources of atmospheric soil dust identified with the NIMBUS 7 Total Ozone Mapping Spectrometer (TOMS) absorbing aerosol product. Rev. Geophys. 40, 1002. http://dx.doi.org/10.1029/2000RG000095.

Sassen, K., Griffin, M.K., Dodd, G.C., 1989. Optical scattering and microphysica properties of subvisual cirrus clouds, and climatic implications. J. Appl. Meteorol. 28, 91-98. http://dx.doi.org/10.1175/1520-0450(1989) 028<0091:osampo>2.0.co;2.

Schumann, U., Weinzierl, B., Reitebuch, O., Schlager, H., Minikin, A., Forster, C., Baumann, R., Sailer, T., Graf, K., Mannstein, H., Voigt, C., Rahm, S., Simmet, R., Scheibe, M., Lichtenstern, M., Stock, P., Rüba, H., Schäuble, D., Tafferner, A. Rautenhaus, M., Gerz, T., Ziereis, H., Krautstrunk, M., Mallaun, C., Gayet, J.F., Lieke, K., Kandler, K., Ebert, M., Weinbruch, S., Stohl, A., Gasteiger, J., Gross, S. Freudenthaler, V., Wiegner, M., Ansmann, A., Tesche, M., Olafsson, H., Sturm, K. 2011. Airborne observations of the Eyjafjalla volcano ash cloud over Europe during air space closure in April and May 2010. Atmos. Chem. Phys. 11, 22452279. http://dx.doi.org/10.5194/acp-11-2245-2011.

Schütz, L., 1980. Long-range transport of desert dust with special emphasis on the Sahara. Ann. N.Y. Acad. Sci. 338, 515-532. http://dx.doi.org/10.1111/j.17496632.1980.tb17144.x

Siebert, L., Simkin, T., Kimberly, P., 2010. Volcanoes of the World, third ed. Berkeley.

Sigmundsson, F., Hreinsdottir, S., Hooper, A., Arnadottir, T., Pedersen, R., Roberts, M.J., Oskarsson, N., Auriac, A., Decriem, J., Einarsson, P., Geirsson, H., Hensch, M. Ofeigsson, B.G., Sturkell, E., Sveinbjornsson, H., Feigl, K.L., 2010. Intrusion triggering of the 2010 Eyjafjallajokull explosive eruption. Nature 468, 426-430. http://dx.doi.org/10.1038/nature09558.

Stohl, A., Prata, A.J., Eckhardt, S., Clarisse, L., Durant, A., Henne, S., Kristiansen, N.I. Minikin, A. Schumann, U., Seibert, P. Stebel, K. Thomas, H.E., Thorsteinsson, T. Torseth, K., Weinzierl, B., 2011. Determination of time- and height-resolved volcanic ash emissions and their use for quantitative ash dispersion modeling: the 2010 Eyjafjallajokull eruption. Atmos. Chem. Phys. 11, 4333-4351. http:// dx.doi.org/10.5194/acp-11-4333-2011.

Turnbull, K., Johnson, B., Marenco, F., Haywood, J., Minikin, A., Weinzierl, B., Schlager, H., Schumann, U., Leadbetter, S., Woolley, A., 2012. A case study of observations of volcanic ash from the Eyjafjallajökull eruption: 1. In situ airborne observations. J. Geophys. Res. 117, D00U12. http://dx.doi.org/10.1029/ 2011 jd016688.

Weinzierl, B., Petzold, A, Esselborn, M., Wirth, M., Rasp, K, Kandler, K, Schütz, L, Koepke, P., Fiebig, M., 2009. Airborne measurements of dust layer properties, particle size distribution and mixing state of Saharan dust during SAMUM 2006 Tellus 61B, 96-117. http://dx.doi.org/10.1111/j.1600-0889.2008.00392.x.

Weinzierl, B., Sauer, D., Esselborn, M. Petzold, A., Veira, A., Rose, M., Mund, S., Wirth, M., Ansmann, A., Tesche, M., Gross, S., Freudenthaler, V., 2011. Microphysical and optical properties of dust and tropical biomass burning aerosol layers in the Cape Verde region - an overview of the airborne in-situ and lidar measurements during SAMUM-2. Tellus 63B, 589-618. http://dx.doi.org/ 10.1111/j.1600-0889.2011.00566.x.

Weissmann, M., Busen, R., Dörnbrack, A., Rahm, S., Reitebuch, O., 2005. Targeted observations with an airborne wind lidar. J. Atmos. Ocean. Technol. 22, 1706 1719. http://dx.doi.org/10.1175/JTECH1801.1.

Wendisch, M., Coe, H., Baumgardner, D., Brenguier, J.L., Dreiling, V., Fiebig, M. Formenti, P., Hermann, M., Kraemer, M., Levin, Z., Maser, R., Mathieu, E., Nacass, P., Noone, K., Osborne, S., Schneider, J., Schuetz, L., Schwarzenboeck, A Stratmann, F., Wilson, J.C., 2004. Aircraft particle inlets: state-of-the-art and future needs. Bull. Am. Meteor. Soc. 85, 89-91. http://dx.doi.org/10.1175/ BAMS-85-1-89.

Witham, C., Webster, H., Hort, M., Jones, A., Thomson, D., 2012. Modelling concentrations of volcanic ash encountered by aircraft in past eruptions. Atmos. Environ. 48, 219-229. http://dx.doi.org/10.1016/j.atmosenv. 2011.06.073. 